NOTICE: this is the author's version of a work that was accepted for publication in Lithos. Changes resulting from the publishing process, such as peer review, editing, corrections, structural formatting, and other quality control mechanisms may not be reflected in this document. Changes may have been made to this work since it was submitted for publication. A definitive version was subsequently published in Lithos, Vol. 178 (2013). DOI: 10.1016/j.lithos.2013.02.002 


\section{The Process of Serpentinization in Dunite from New Caledonia}

\section{By}

B. Ronald Frost ${ }^{1}$, Katy Evans ${ }^{2, *}$, Susan M. Swapp $^{1}$, James S. Beard ${ }^{3}$

1. Department of Geology and geophysics, University of Wyoming, Laramie, WY 82072, USA. (rfrost@uwyo.edu, swapp@uwyo.edu)

2. Department of Applied Geology, Curtin University of Technology, Bentley, WA 6845, Australia

3. Virginia Museum of Natural History, 21 Starling Ave. Martinsville, VA. 24112, USA

$$
\text { (jbeard@nsf.gov) }
$$

*Corresponding author: Tel: +61 8 92664682, e-mail: K.Evans@curtin.edu.au

Keywords: New Caledonia ophiolite, serpentinization, serpentine, brucite, magnetite, oxygen fugacity, hydrogen 


\section{Abstract}

Dunite from New Caledonia displays three types of veins. The earliest, type 1 veins are narrow $(50-100 \mu \mathrm{m}$ wide $)$ and rarely extend across more than a single olivine grain. They contain abundant brucite and never contain magnetite. Type 2 veins are 0.01 to 0.1 mm wide, extend across several olivine grains and cut across the type 1 veins. They are cored by magnetite and contain less brucite than type 1 veins. Type 3 veins are $\mathrm{cm}$-scale, have a magnetite-rich core, and extend for meters or more. The type 1 veins have relatively Fe-rich serpentine $\left(\mathrm{X}_{\mathrm{Mg}}=0.92\right)$ and brucite $\left(\mathrm{X}_{\mathrm{Mg}}=0.82\right)$. These minerals are more magnesian than those in the type 2 veins; serpentine has $\mathrm{X}_{\mathrm{Mg}}=0.93-0.94$ and brucite has $\mathrm{X}_{\mathrm{Mg}}=0.84$. In the magnetite-rich core to the type 3 vein both serpentine $\left(\mathrm{X}_{\mathrm{Mg}}\right.$ $=0.94-0.97)$ and brucite $\left(\mathrm{X}_{\mathrm{Mg}}=0.94\right)$ are $\mathrm{Mg}$-rich. Opx in harzburgite layers in these samples is cut by serpentine veins that are on the order of $0.05 \mathrm{~mm}$ wide. The veins lack talc or magnetite and, as with veins cutting olivine, the older veins are more Fe rich $\left(\mathrm{X}_{\mathrm{Mg}}\right.$ $=0.84)$ than the younger veins $\left(X_{M g}=0.90\right)$. We conclude that the formation of magnetite was accompanied by the extraction of iron from the early-formed serpentine and brucite.

Thermodynamic calculations suggest that the type 1 veins formed in a rockbuffered system where the activities of $\mathrm{FeO}, \mathrm{MgO}$, and $\mathrm{SiO}_{2}$ were dictated by the compositions of olivine and orthopyroxene. In contrast the type 2 veins were formed in a more fluid-buffered system where the infiltrating fluid was relatively oxidizing and out of equilibrium with the original brucite-serpentine assemblage. Reduction of this fluid was accompanied by reaction of brucite and serpentine to magnetite and hydrogen. In addition to producing magnetite this reaction also extracted iron from brucite and 
serpentine, making them both more magnesian. This would drive the brucite-serpentinemagnetite buffer to higher oxygen fugacity, progressively decreasing the efficiency of the magnetite-forming reactions.

\section{Introduction}

Serpentinization is an important geochemical process accompanying the formation of the ocean floor. The hydration of peridotites not only induces huge rheological changes in the oceanic crust, it produces reduced seafloor vents (Beard and Hopkinson, 2000, Kelley, et al., 2001, Charlou et al., 2002) that recently have been postulated to be an ideal environment for the origin of life (Russell and Hall, 1997; Sleep et al. 2004, Russell and Arndt, 2005). Additionally, partially serpentinized ultramafic rocks have been proposed as potential hosts for sequestration of anthropogenically-produced carbon (e.g. Kelemen and Matter, 2009).

Peridotites and their metamorphic equivalents are chemically relatively rather simple. They can, for most purposes, be described by the system $\mathrm{CaO}-\mathrm{MgO}-\mathrm{FeO}-$ $\mathrm{SiO}_{2}-\mathrm{H}_{2} \mathrm{O}-\mathrm{O}$. However, the processes that transform olivine and pyroxene to serpentine and other products are still a matter of considerable debate (Frost and Beard, 2007; Evans, 2008). Frost and Beard (2007) propose that formation of magnetite is driven by loss of $\mathrm{SiO}_{2}$ from iron-bearing serpentine or brucite, and that low water and silica activities stabilize magnetite- and Fe-alloy- bearing assemblages relative to serpentine and brucite. Evans (2008), on the other hand, proposes that magnetite and iron alloys form because the $\mathrm{X}_{\mathrm{Mg}}$ of serpentine and brucite in equilibrium with olivine or 
orthopyroxene is higher than that of the bulk rock, so excess Fe must then be hosted by Si-poor phases such as magnetite or iron alloys.

If we are to predict the conditions under which the various serpentinite assemblages form and understand the environments that form serpentinites then it is essential that we distinguish between these possibilities, as each has distinctly different implications for the parameters that control the serpentinizing environment. The formation of magnetite, and the behavior of iron generally, is particularly critical, because it is iron-bearing reactions that drive serpentinizing environments to extremely low $f \mathrm{O}_{2}$ values via the production of ferric iron accompanied by the reduction of water to hydrogen. Because of these reducing conditions Russell and Hall, (1997), Sleep et al. (2004) and Russell and Arndt (2005) have suggested serpentinizing environments as the cradle for early life. Thus the chemical influences on these environments must be understood if the initiation of life is to be successfully modeled or simulated.

Additionally, the process of serpentinization offers an opportunity to study metamorphic environments in which equilibrium is only reached, if it is reached at all, on very limited length-scales. Such environments are of increasing interest as the scope of metamorphic studies extends to lower temperatures, and to situations where bulk composition may not be fixed on the length-scale of interest (i.e. metasomatic systems). Equilibrium thermodynamics has provided valuable insights into metamorphism at greenschist grade and higher, but application of equilibrium techniques to lower temperature environments requires careful assessment of the existence, or otherwise, of thermodynamic equilibrium, and the length-scales on which it is attained. The chemical simplicity of serpentinizing environments facilitates this task. 
In this paper we make a detailed study of serpentine veins in dunite from New Caledonia. Results are used to constrain the reactions involved in the formation of ironbearing phases, drivers of low oxygen fugacity conditions, and the length-scales and extent of thermodynamic equilibrium during serpentinization.

\section{Regional Geology}

The island of New Caledonia represents the exposed portion of Norfolk Ridge, a microcontinent that rifted from the eastern Gondwanaland margin during the late Cretaceous. The oldest rocks on the island consist of a series of accretionary terranes that include a suite of Permian to Jurassic island arc-derived strata, schistose rocks that were locally metamorphosed to blueschist facies in the Jurassic, fragments of a Triassic ophiolite, and a suite of volcanic rocks and sediments of island arc affinity that extends into the Jurassic (Aitchison et al., 1995). These rocks are unconformably overlain by a transgressive Upper Cretaceous sequence that ranges from conglomerates and coal measures upwards to shallow marine sandstones. For the sake of this paper we refer to this whole sequence as the basement (Fig. 1). Overlying the basement are three westward-directed thrust sheets. Lying on the northwestern portion of the island is a sheet composed mostly of basalt and minor ocean-floor sediments that is called the Poya terrane (Cluzel et al., 2001). On the northeastern portion of the island is a sheet of highpressure rocks known as the Pouebo terrane (Cluzel et al, 2001) that are mostly in blueschist facies but locally have been metamorphosed up to eclogite facies (Clarke et al., 1997). U-Pb zircon ages indicate that the peak metamorphism in the Pouebo terrane 
occurred around $44 \mathrm{Ma}$ (Spandler et al., 2005). Lying structurally above the other two is a thrust sheet of ophiolite that is most extensively exposed as the Massif du Sud in the southern part of the island, but which occurs as klippes along the whole island. Thrusting is constrained to have occurred in the Eocene. Stratigraphic relations constrain the Poya terrane to have been emplaced between 33.7 and $35 \mathrm{Ma}$ (Cluzel et al., 2001) and apatite fission track dating implies that the Pouebo terrane was emplaced at $34 \mathrm{Ma}$ (Baldwin et al., 2007). The ophiolite was emplaced between $34 \mathrm{Ma}$, the age of the youngest sediment beneath the nappe, and $27 \mathrm{Ma}$, the age of stitching plutons that intrude the nappe (Cluzel, et al., 2006). After the emplacement of the nappes, New Caledonia has been subjected to extension that began in the Miocene and has extended to the Neogene (Lagabrielle et al., 2006, Cluzel et al, 2001; Rawling and Lister, 2002).

The New Caledonian ophiolite consists mainly of harzburgite and dunite (Titus et al. 2011), with minor gabbro. The peridotite has been extensively weathered to laterite and ferricrete over much of the island, but spectacular exposures are present in areas of active erosion. The samples we studied came from downstream of Yate dam, where the Yaté River has exposed an extensive area of fresh outcrops (Fig. 1).

\section{Sample Description}

The peridotite exposed along the Yaté River is mostly harzburgite containing 10 $\mathrm{cm}$ - to 1 meter-wide bands of dunite that lie parallel to the foliation. Also present are 1 $\mathrm{cm}$ - to $10 \mathrm{~cm}$-wide orthopyroxenite veins that cut the foliation. Serpentinization ranges 
from $20 \%$ to more than $60 \%$ and becomes more intense adjacent to widely spaced serpentinized fault zones that are from meters to tens of meters wide.

We studied two olivine-rich samples in detail, NC09-05, and NC09-11. NC09-05 comes from the riverbed about 500 meters downstream of Yaté Dam; NC09-11 comes from approximately 250 meters further downstream. NC09-05 was collected because it displayed the contact between harzburgite and dunite (Fig. 2) whereas NC09-11 was collected because it contained a cm-wide serpentinite vein (Fig. 3) cutting dunite. Both samples consist mainly of olivine with minor chromite; the harzburgite portions of NC0905 also contain about $10-15 \%$ Opx with fine Cpx lamellae. NC09-05 contains about $30 \%$ serpentine that is uniformly distributed throughout. Sample NC09-11 contains 50\% serpentine in regions distal to the large vein. The serpentine abundance increases to $100 \%$ within about $0.5 \mathrm{~cm}$ from the vein.

To determine the geochemical processes attendant to vein formation, we analyzed in detail five types of serpentine veins that we recognized in these two samples. As with rocks described by Beard et al. (2009), the initial stage of serpentinization in the New Caledonia rocks involves two types of serpentine veins. Type 1 veins are narrow (about $50-100 \mu \mathrm{m}$ wide) and rarely extend across more than a single olivine grain (Fig. 4a). They never contain magnetite and contain brucite that is generally more abundant adjacent to the olivine. Type 2 veins are 0.01 to $0.1 \mathrm{~mm}$ wide and cut across the type 1 veins (Fig.4a, b). They rarely extend for more than $2 \mathrm{~mm}$ before being terminated by an en-echelon manner or being cut by another type 2 vein. Magnetite is commonly found in the cores of the type 2 veins and brucite may be present on the margins. Further serpentinization results in formation of type 3 veins. The type 3 veins are $\mathrm{cm}$-scale veins 
that extend for meters or more. We studied a type 3 vein in NC09-11 that is slightly less than $1 \mathrm{~cm}$ across (Fig. 3) and contains a distinct magnetite-rich core. We also studied two types of veins that cut Opx crystals in harzburgitic layers within the dunite from sample 09NC-05. The veins, neither of which contains magnetite, are on the order of $0.05 \mathrm{~mm}$ wide. One type is pale yellow in PPL and the other is pale green (Fig. 4c).

\section{Analytical Procedures}

Mineral analyses were determined on a JEOL 8900 Superprobe at the University of Wyoming using $15 \mathrm{Kv}$ voltage and a sample current of $20 \mathrm{nA}$. Raw counts were corrected using the ZAF procedure. Because serpentine in the veins is locally intimately intergrown with brucite, we chose to make approximately 100 point-analyses within a small area of each vein. Backscattered electron images (BSE) and X-ray element maps were obtained at the University of Wyoming using a FEI Quanta 450 field emission scanning electron microscope equipped with an Oxford INCA solid state X-ray analysis system.

\subsection{SEM and X-ray maps}

BSE and X-ray maps show that the type 1 veins are crudely zoned with brucite abundant on the margins of the veins and serpentine more abundance in the cores (Fig. 5). Brucite is more iron-rich than serpentine and this allows one to recognize, both in the element maps and the SEM image, that the two minerals appear to be mixed on a very 
fine length scale. BSE and element maps from the type 2 vein in Fig. 4a show that the vein contains a brucite-rich margin similar to the type 1 vein and patches within the interior of the vein where serpentine and brucite appear to be intimately intergrown (Fig. 6). The core of the large type 2 vein in Fig. $4 \mathrm{~b}$ shows that even in the wide type 2 veins there is inhomogeneity in silica, $\mathrm{Mg}$, and Fe (Fig. 7), suggesting an intergrowth of relatively iron-rich brucite and more magnesian serpentine. A reasonable explanation for the spotty distribution of brucite-rich areas in Figure 7 is that they record the previous locations of vein margins. This implies that the large type 2 vein formed from numerous fractures that cut the original dunite, the margins of which each had brucite enrichment similar to what is seen in Figures 5 and 6. The magnetite-rich core to the type 3 vein in NC09-11 (Fig 3) contains patches of brucite, some of which are touching magnetite (Fig. 8). Unlike the brucite in the type 1 and type 2 veins, the brucite in this vein is more magnesian than the serpentine.

The serpentine veins cutting the Opx are more homogenous than those cutting olivine (Figs. 9,10), although subtle compositional variations are evident, especially in the BSE image. The two colors of serpentine clearly have different compositions. The older, green vein is more iron-rich than the Opx from which it formed whereas the yellow one has nearly the same Fe content as the Opx. Figure 10 also shows that the iron-poor yellow vein clearly cuts the iron-rich green vein, something that is not evident in the photomicrograph (Figure 4).

\section{Mineral analyses}


To get an estimate of the mass balance of the serpentinization reaction, for each area we analyzed a grid of 100 or more points. Individual point analyses from the veins show a wide range in composition that is informatively displayed in a plot of $\mathrm{Si}$ atoms in the formula versus the total of $\mathrm{Fe}+\mathrm{Mg}$ atoms (Fig. 11) or against $\mathrm{X}_{\mathrm{Mg}}$ (Fig. 12). In our calculations we normalized the cation proportions to 7 oxygens, which is what is used in calculating a serpentine formula. Analyses from the type 1 (Fig. 4a, Fig. 5) vein cover nearly the whole range in compositions between brucite and serpentine (Fig. 11a, 12a), with a distinct break between the brucite-rich and the serpentine-rich analyses.

Analyses of the small type 2 vein (Fig. 4a, Fig 6) and the large type 2 vein (Fig. 4b, Fig 7) also spread from stoichiometric serpentine towards brucite, (Fig. 11b,c 12b,c) but with far fewer points on the brucite end of the spectrum. In addition, the trend outlined by the analyses for the type 2 veins in Figure $12 \mathrm{~b}$ and $\mathrm{c}$ have shallower slopes than that for the type 1 vein, suggesting that the brucite end member in type 2 veins has a higher $X_{\mathrm{Mg}}$ than brucite in the type 1 vein. A plot of $\mathrm{Si}+\mathrm{Al} / 2$ versus Fe shows that the substitution of Fe into the serpentine structure in the type 1 veins is distinct from the cronstedtite substitution curve of Evans (2008) (Fig. 13a). Since the substitution trend appears to involve a mixture of serpentine and brucite and since the iron in brucite is ferrous (O’Hanley and Dyar, 1993), we conclude that the iron in the brucite components in this vein is likely to be dominantly ferrous. In contrast to the type 1 veins, there is a subtle indication that the most $\mathrm{Si}$-rich serpentines in the thicker type 2 vein may have a slight cronstedtite substitution (Fig. 13c), and hence may contain considerable ferric iron. 
The array of analyses from the thick type 3 vein in NC09-11 is broad and complex. The serpentine has compositions ranging from serpentine to close to brucite (Fig. 11c) but on the plot of $\mathrm{X}_{\mathrm{Mg}}$ versus $\mathrm{Si}$ there seems to be at least two compositions of brucite involved (Fig. 12d). One trend is toward a brucite with $\mathrm{X}_{\mathrm{Mg}} \sim 0.86$ and the other is toward brucite with $\mathrm{X}_{\mathrm{Mg}} \sim 0.93$. The analyses that have the trend toward the high $\mathrm{Fe}$ brucite lies on the margins of the large vein, whereas the analyses trending toward the magnesian brucite is associated with magnetite in the interior of the vein. Trends on the $\mathrm{Si}+\mathrm{Al} / 2$ vs. Fe plot for the type 3 vein (Fig. 13d) are also consistent with the bimodal brucite compositions.

As suggested by the BSE and element maps (Figs 9 and 10) there are two serpentine compositions in veins cutting the Opx, both of which are compositionally distinct from the serpentine forming from olivine. Both types of serpentine are more siliceous than the serpentine forming from olivine and they lack compositions that extend toward brucite (Fig 11e,f). In addition, they are more iron-rich than serpentine forming from olivine (Figs 12e,f). The yellow serpentine has nearly the same $\mathrm{X}_{\mathrm{Mg}}$ as the Opx it cuts, whereas the green serpentine is considerably more iron-rich than the host Opx or the yellow serpentine vein that cuts it (Fig. 12f). The Opx-cutting serpentine also plots differently to the olivine-cutting serpentines in $\mathrm{Fe}-\mathrm{Si}+\mathrm{Al} / 2$ space, suggesting the presence of a greater cronstedtite component than in the serpentine cutting olivine. 


\subsection{Average Mineral Compositions}

In calculating the average mineral analyses tabulated in Table 1 from the many point analyses in each area we used the following reasoning:

1) Those analyses that totaled to $99 \%$ or more were considered to be from olivine or Opx, depending on which mineral was hosting the vein.

2) Analyses with totals between 98 and $86 \%$ were considered to be mixtures of serpentine with olivine or Opx and were not used in calculating the totals.

3) Those analyses with totals below $86 \%$ and with more than 1.9 moles of silica per formula unit (when calculated to 7 oxygens) were considered to be relatively pure serpentine.

4) Those analyses with totals below $86 \%$ and having less than 0.1 mole of silica per formula unit were considered to be brucite, unless the analysis contained nearly no $\mathrm{MgO}$, in which case it was considered to be a mixture with magnetite, and was not used.

\subsubsection{Olivine and Opx.}

The olivine, at $\mathrm{Fo}_{91}$ and around $0.4 \% \mathrm{NiO}$, has a composition characteristic of mantle olivine (Table 1). As is typical of mantle rocks, the Opx is slightly more magnesian than the coexisting olivine. The Opx has 0.66 wt. \% $\mathrm{CaO}$, a composition that would be consistent with a minimum equilibration temperature (i.e. conditions where it would have been in equilibrium with augite) of ca. $950^{\circ} \mathrm{C}$ (Anderson et al., 1993). 


\subsubsection{Serpentine.}

Our analyses show that serpentine from both NC09-05 and NC09-11 shows a range of composition that is dependant on the mineral assemblages with which it is associated (Table 1). Serpentine from the type 1 vein in NC09-05 is moderately iron rich with $\mathrm{X}_{\mathrm{Mg}}$ $=0.923$, whereas that from nearby type 2 veins is more magnesian with $\mathrm{X}_{\mathrm{Mg}}=0.934$. Serpentine from the large type 2 vein in NC09-05 is even more magnesian with $\mathrm{X}_{\mathrm{Mg}}=$ 0.941 , although a small population of serpentine from the vein, and which are spatially associated with brucite-rich areas is somewhat more iron rich with $\mathrm{X}_{\mathrm{Mg}}=0.909$. Serpentine from the core of the large type 3 vein in NC09-11 where it coexists with magnetite is highly magnesian $\left(\mathrm{X}_{\mathrm{Mg}}=0.969\right)$, whereas away from the magnetite it is more iron-rich with $\mathrm{X}_{\mathrm{Mg}}=0.944$.

Similar to the serpentine forming from olivine, serpentine from magnetite-free veins cutting Opx also shows complex chemistry. This serpentine has much higher $\mathrm{Al}_{2} \mathrm{O}_{3}$ and $\mathrm{CaO}$ than the serpentine forming from olivine and it is much richer in iron. The veins that are green in PPL have $\mathrm{X}_{\mathrm{Mg}}=0.839$, whereas that which is yellow has $\mathrm{X}_{\mathrm{Mg}}=0.897-$ 0.899. It is clear that the more iron-rich serpentine is earlier than the Mg-rich variety, since the Mg-rich variety cuts the Fe-rich serpentine (Fig. 10). Both the yellow serpentine and green serpentines a flatter slope of $\mathrm{Si}+\mathrm{Al} / 2$ versus Fe than is dictated by

cronstedtite (Fig 13e,f), suggesting that the iron substitution may be via a combination of the cronstedtite substitution and a Fe $\mathrm{Mg}^{-1}$ exchange. They plot in a similar way to the iron-rich lizardite forming from Opx described by Evans et al. (2009). 


\subsubsection{Brucite.}

Our analyses of brucite all show small amounts of silica, with the brucite from NC09-05 having around 2.0\% and those from NC09-11 having around 0.5\%.

Considering that wet-chemical analyses of brucite tabulated by Deer et al. (1962) and microprobe analyses by Peretti (1988) contain no silica, we contend that these low silica contents represent an admixture of serpentine that was interlayered at a fine scale, as was indicated on SEM images. Despite the small admixture of serpentine in brucite, we can

use the analyses tabulated on Table 1 to calculate a $\mathrm{K}_{\mathrm{d}}\left(K_{d}=\left(X_{M g}^{B r c} / X_{F e}^{B r c}\right) x\left(X_{F e}^{S r p} / X_{M g}^{S r p}\right)\right)$ between brucite and serpentine (Fig. 14).

The serpentine-brucite pairs from NC09-05 have a $\mathrm{K}_{\mathrm{d}}$ of around 0.37 , assuming that most of the iron in serpentine is ferrous. This $K_{d}$ would be lower if some of the iron were ferric. The similar Kd values for the type 1 and type 2 veins support the notion of thermodynamic equilibrium on some length scale for co-existing serpentine and brucite. This $K_{d}$ is much lower than the $K_{d}$ of 0.5 calculated for serpentine-brucite pairs from metamorphosed serpentinites by Evans and Trommsdorff (1975) but still lies within the envelope of serpentine and brucite data from the literature (Figure 14). The serpentine brucite pair from the type 3 vein are both more magnesian and lie on a line defined by $\mathrm{K}_{\mathrm{d}}$ $=1.34$.

\section{Mass Balance calculations}

It is clear from the textures that hydration of NC09-05 and NC09-11 proceeded differently, depending on whether the precursor mineral was olivine or Opx. If hydration 
was isochemical, apart from water, then hydration in the olivine domains can be represented, for $\mathrm{Mg}$ end-members, by:

$$
2 \mathrm{Mg}_{2} \mathrm{SiO}_{4}+3 \mathrm{H}_{2} \mathrm{O}=\mathrm{Mg}_{3} \mathrm{Si}_{2} \mathrm{O}_{5}(\mathrm{OH})_{4}+\mathrm{Mg}(\mathrm{OH})_{2}
$$

Because no talc was found in the hydration veins in the Opx, the isochemical hydration of the Opx domain to serpentine without other products would have occurred by the reaction:

$$
3 \mathrm{MgSiO}_{3}+2 \mathrm{H}_{2} \mathrm{O}=\mathrm{Mg}_{3} \mathrm{Si}_{2} \mathrm{O}_{5}(\mathrm{OH})_{4}+\mathrm{SiO}_{2(\mathrm{aq})}
$$

The silica released by reaction (2) would be consumed by the reaction of brucite, located in the olivine domains, to serpentine:

$$
3 \mathrm{Mg}(\mathrm{OH})_{2}+2 \mathrm{SiO}_{2(\mathrm{aq})}=\mathrm{Mg}_{3} \mathrm{Si}_{2} \mathrm{O}_{5}(\mathrm{OH})_{4}+\mathrm{H}_{2} \mathrm{O}
$$

Thus, the reaction in the olivine domain is a combination of reactions (1) and (3) but the relative progress of the two reactions cannot be specified because it depends on the relative progress of the hydration of olivine and Opx (reactions (1) and (2)) and the efficiency of silica transport in the fluid phase, which controls the extent of reaction (3).

To quantify the mass balance of the vein formation process we used the isocon diagrams of Grant (1986) (Fig. 15). These diagrams compare the composition of the original rock, calculated from the composition of the original olivine and Opx, to the composition of the altered rocks, calculated from the bulk composition of the veins. In these diagrams conserved oxides lie on a line; those oxides that have been added to the system lie above the line and those that have been extracted lie below the line.

For the type 1 vein there, initially, is no clear indication that any oxide components were conserved (solid symbols, Fig. 15a). However if one subtracts about $20 \%$ of the average brucite composition (Table 1) from the average vein composition, all 
oxides, apart from $\mathrm{CaO}$, end up nearly collinear. This is consistent with a nearisochemical hydration process averaged over an area larger than the one chosen here for analysis, i.e. the area we chose to integrate had a greater than representative quantity of brucite. It is evident from Figure 5 that brucite is irregularly distributed in the type 1 veins indicating that $\mathrm{SiO}_{2}, \mathrm{MgO}$, and $\mathrm{FeO}$ were mobile at least on the scale of $100 \mu \mathrm{m}$.

The oxide components for the small type 2 vein in area 1 (Fig. 6) apart from $\mathrm{CaO}$ are collinear (Figure 15b), suggesting that the vein could have formed in a isochemical manner. Behavior of the oxide components for the larger type 2 vein (Fig. 4a, Fig. 7) is more complex (Figure 15c). If we assume that $\mathrm{MgO}$ was conserved, then small amounts of silica $(\sim 1.5 \%)$ would have been added. Additionally, either small amounts of FeO $(\sim 0.7 \%)$ were extracted from the vein or our microprobe integration of the vein missed a small amount of magnetite. Relations are similar for the large vein in sample NC09-11 (Fig. 15d). FeO plots below the reference line but it would plot on the line if about $2.5 \%$ magnetite were added. Even accounting for the fact that the analyses could have missed a small amount of magnetite, the results suggest that, if $\mathrm{MgO}$ were conserved, small amounts of silica (about 3\%) were added to the vein.

Unlike the veins in olivine, which can be described as being nearly isochemical (apart from some movement of silica) the veins in Opx look as if they were formed in an open system (Figs. 15e,f). For comparisons only we have drawn a reference line for the yellow serpentine (Figs. 15e,f) assuming $\mathrm{MgO}, \mathrm{FeO}$ and $\mathrm{MnO}$ were conserved, since they are nearly collinear. If this were true, then the formation of the yellow vein involved extraction of about $18 \% \mathrm{SiO}_{2}$, as well as significant amounts of $\mathrm{CaO}, \mathrm{Al}_{2} \mathrm{O}_{3}$, and $\mathrm{NiO}$ (Fig. 15 e,f). For the green iron-rich serpentine cutting Opx it is likely that iron was 
added and silica depleted (Fig. 15f), but the complexity of the system is such that, with our present data, we cannot say exactly what the mass-balance reactions were.

The elemental mobility is obvious in the BSE images (Fig. 4a). The compositional variation we see in the veins is not distributed uniformly across the vein. In the serpentine veins cutting olivine, brucite, and hence $\mathrm{FeO}$ and $\mathrm{MgO}$, is most likely to be concentrated on the margins of the vein and the Si-rich serpentine is more likely to occupy the cores. Similarly in the veins cutting Opx the serpentine on the margin is relatively enriched in silica and the core is enriched in $\mathrm{MgO}$ and $\mathrm{FeO}$.

It is evident from the information above that mineral assemblages and compositions of serpentine and brucite change as the hydration of serpentine proceeds. The first assemblage formed from olivine is the serpentine-brucite assemblage found in the type 1 veins (see also Beard et al, 2009). The brucite in these veins is rather iron-rich. Although the average $\mathrm{X}_{\mathrm{Mg}}$ for brucite in the type 1 veins is 0.82 (Table 1), Figure 12a indicates that it could range from less than 0.80 to nearly 0.84 . Brucite is far less abundant in the type 2 veins, which contain the assemblage serpentine-brucite-magnetite, in which the brucite never touches the magnetite, (Fig. 6). The brucite that is present is more magnesian and close in composition to the most magnesian brucite in the type 1 veins. Since the type 2 veins cut the type 1 veins the logical conclusion is that the first brucite to form is relatively iron-rich and as hydration proceeds, the brucite becomes more magnesian. Similar relations are seen in NC09-11. The serpentine and brucite on the margins of the vein, where there is no magnetite are relatively iron-rich and define a trend that extends toward a brucite with $\mathrm{X}_{\mathrm{Mg}}=0.86$. In the core of the vein where magnetite is present the 
brucite is much more magnesian $\left(\mathrm{X}_{\mathrm{Mg}}=0.94\right)$ and is nearly as magnesian as the coexisting serpentine.

\section{Discussion and Conclusions}

\subsection{Element mobility and magnetite formation}

An important observation arising from this work is that in the initial stages of serpentinization the composition of serpentine varies, depending whether the serpentine is forming after olivine or Opx. In addition, as serpentinization of olivine proceeds, the composition of serpentine changes, in response to changes in silica activity, oxygen fugacity, water activity and, potentially, other parameters such as pressure and temperature. The serpentine in the type 3 vein in NC09-11 has distinctly different compositional trends from the serpentine in the thinner type 1 or type 2 veins in dunite from NC09-05. This difference may reflect the fact that the vein in NC09-11 formed at lower temperature than the disseminated serpentine veins in $\mathrm{NC} 09-05$, but it is more likely to be caused by the fact that the serpentine in the coarse vein is far removed from olivine (at least $0.5 \mathrm{~cm}$ ) and probably equilibrated at a different silica activity and oxygen fugacity than serpentine in an olivine-dominated system. In addition the serpentine within Opx in NC09-05 has a different composition from serpentine in olivine. It is likely that the compositional differences we see in all these serpentine veins would diffuse away in a rock that has been completely serpentinized, eliminating the evidence of chemical relations early in the serpentinization process. This means that one cannot 
use the composition of serpentine from metaperidotite that has been completely serpentinized or that have undergone regional metamorphism to constrain the processes of serpentinization (Evans, 2008).

Another important conclusion is that the type 1 veins in olivine could have formed by simple hydration without any necessity for element movement on a scale greater than 100 microns, or the need for magnetite to accommodate iron. A model reaction for the formation of this vein is:

$$
\begin{array}{cccc}
2 \mathrm{Mg}_{1.82} \mathrm{Fe}_{0.18} \mathrm{SiO}_{4} & +3 \mathrm{H}_{2} \mathrm{O} & =\mathrm{Mg}_{2.82} \mathrm{Fe}_{0.18} \mathrm{Si}_{2} \mathrm{O}_{5}(\mathrm{OH})_{4} & \\
\text { olivine } & \text { fluid } & \text { serpentine } & \text { brucite }
\end{array}
$$

The composition for the model serpentine in reaction (4) is a bit more siliceous and magnesian than the average serpentine listed in Table 1 because we have projected the serpentine composition to a silica content of two atoms per formula (see Fig. 5). This reaction is similar to reactions derived by Bach et al. (2006) and Beard et al. (2009) and suggests that the theory put forward by Evans (2008), that magnetite forms in serpentinites because the amount of iron in olivine cannot be accommodated in the hydration products, does not hold for this sample, as magnetite is not part of the initial hydration assemblage.

The increased $\mathrm{X}_{\mathrm{Mg}}$ in brucite and serpentine in the immediate vicinity of magnetite in type 2 and 3 veins suggests that formation of magnetite in these veins involves a reaction that involves the extraction of Fe from both brucite and serpentine. This mechanism for the formation of magnetite has been postulated by Bach et al. (2006) and Beard et al. (2009). 


\subsection{Constraints from equilibrium thermodynamic modeling}

Differences in mineral assemblage and composition on the mm-scale, such that olivine- and Opx-dominated domains are clearly distinguishable (e.g. Fig. 13), suggest that thermodynamic equilibrium, if it exists in these samples at all, exists on a relatively limited length-scale. Additionally, even if mutual equilibrium links the compositions of brucite, serpentine and magnetite, as suggested by the consistent trends on Figs. 11 to 13, it is unclear whether relict olivine and Opx are in equilibrium with their hydration products, or if the relicts are metastable, in which case the serpentinizing system is at partial equilibrium, at most. These issues pose significant problems for the application of thermodynamic models. Nevertheless, valuable insights can be gained if such models are applied with care. For example, it is possible to calculate the response of mineral compositions to changes in extensive and intensive parameters such as the chemical potentials of water, $\mathrm{SiO}_{2}$ and bulk $\mathrm{X}_{\mathrm{Mg}}$, and to use a comparison of calculated and observed compositions to constrain the co-variation of these critical parameters and test serpentinization models.

Calculations were performed using THERMOCALC v. 335i (Powell et al., 1998) with the ds60 dataset (Holland and Powell, 2011). The components considered were FMOSH (FeO-MgO-O-SiO $\left.2-\mathrm{H}_{2} \mathrm{O}\right)$. Details of end-member properties and activitycomposition relationships are described by Evans (submitted to Lithos, July 2012). The model successfully reproduces mineral compositions reported in the literature from a wide range of serpentinizing environments and temperatures (e.g. Hostetler et al., 1966; 
O'Hanley and Dyar, 1998; D'Antonio and Christensen, 2004; Shervais, 2005; Groppo et al., 2006; Frost et al., 2008; Vils et al., 2008; Beard and Frost, 2009).

The fluid was modeled as a $\mathrm{H}_{2} \mathrm{O}-\mathrm{H}_{2}$ mixture because $\mathrm{H}_{2}$ may become a significant proportion of fluids at the conditions investigated. The alloy phase is intended as a proxy for awaruite $\left(\mathrm{Ni}_{3} \mathrm{Fe}\right)$. Nickel is not included in the system considered, so the alloy phase was modeled by Fe with an activity of 0.25 i.e. awaruite was assumed to be a mechanical mixture and ideal mixing was assumed. These assumptions are clearly an oversimplification. However, constraints on the composition of the alloy phase in the rocks were lacking, so these assumptions are appropriate for the level of modeling undertaken. Magnetite was modeled as pure magnetite, as there is little evidence for significant proportion of elements other than $\mathrm{Fe}$ and $\mathrm{O}$ in this phase. Cr-rich magnetite may rim spinel in these rocks; the magnetite in the serpentine veins is invariably $\mathrm{Cr}$-free. $\log f \mathrm{O}_{2}$ was calculated assuming a standard state of pure oxygen gas at 1 bar and the temperature of interest. $\log a \mathrm{SiO}_{2}$ was calculated assuming a standard state of pure quartz at the pressure and temperature of interest.

\subsubsection{Stability of olivine and Opx during serpentinization.}

Initially, the likelihood of olivine and Opx equilibration with the serpentine-brucitemagnetite assemblages was assessed via a pseudosection approach (Fig. 16a).

Pseudosections are phase diagrams calculated for a fixed bulk composition; the bulk composition used was that of a typical New Caledonia peridotite (c.f. Evans, 2012). Small changes in bulk composition do not change the location of the field boundaries significantly. Two points are worthy of note. First, olivine and brucite are predicted to 
co-exist over only a very small temperature range $\left(0.02{ }^{\circ} \mathrm{C}\right)$, though this assemblage is common in partially serpentinized rocks. Second, Opx is not stable with the hydrated phases at temperatures less than $600^{\circ} \mathrm{C}$. This temperature is certainly higher than temperatures associated with serpentine growth in NC09-05 and NC09-11, which contain abundant lizardite rather than antigorite. From these observations we must conclude that olivine and Opx are relict phases that are not in thermodynamic equilibrium with the surrounding hydrated assemblage, though local equilibrium could occur if water activities dropped to significantly less than 1 . Calculations with water activity set to 0.6 decrease the olivine-out temperature from 368 to $327^{\circ} \mathrm{C}$, while further decreases in water activity led to destabilization of brucite, producing the stable assemblage is serpentine-olivinemagnetite, which is not observed. This result places a maximum on water activity of around 0.5 if local equilibrium was achieved.

\subsubsection{Stability relations of serpentine, brucite, and magnetite.}

Further modeling investigated the relative stability and compositions of co-existing serpentine, brucite and magnetite. These parameters were calculated as a function of the chemical potentials of $\mathrm{SiO}_{2}$ and $\mathrm{O}_{2}$ at $200^{\circ} \mathrm{C}$ and $0.1 \mathrm{GPa}$ for a range of bulk $\mathrm{X}_{\mathrm{Mg}}$ values (Fig 16b). Figure $16 \mathrm{~b}$ also shows isopleths for constant $\mathrm{X}_{\mathrm{Mg}}$ in serpentine. $\mathrm{X}_{\mathrm{Mg}}$ was calculated from the modeled mineral compositions as $\mathrm{Mg}^{2+} /\left(\mathrm{Mg}^{2+}+\mathrm{Fe}^{2+}+\mathrm{Fe}^{3+}\right.$ octahedral $)$ i.e. $\mathrm{Fe}^{3+}$ on the tetrahedral site was not included in the calculations. However, in any case, the modeled cronstedtite proportion was relatively small (always $<3 \%$ ) so $\mathrm{X}_{\mathrm{Mg}}$ is approximately equal to $\mathrm{Mg} /\left(\mathrm{Mg}+\mathrm{Fe}_{\text {tot }}\right)$. The calculated diagrams replicate the observed assemblages well, although the serpentine-brucite-magnetite assemblage lies at oxygen 
fugacities above those where an alloy phase such as awaruite is likely to be stable (Fig. 16b). Serpentine and brucite coexist over a range of $f \mathrm{O}_{2}$ in a divariant field with relatively restricted $\mu_{\mathrm{SiO} 2}$ (Fig. 16b). The serpentine - brucite - magnetite assemblage exists on a univariant line with a negative slope in $f \mathrm{O}_{2}-\mu_{\mathrm{SiO} 2}$ space, and the serpentine and serpentine - magnetite assemblages occur at low and high $f \mathrm{O}_{2}$ values respectively at $\mu_{\mathrm{SiO} 2}$ values higher than the serpentine - brucite field. Vein assemblages for vein types 1 , 2 and 3 plot with increasing $f \mathrm{O}_{2}$ at a near-constant $\mu_{\mathrm{SiO} 2}$, while the Opx-domain veins plot at higher $\mu_{\mathrm{SiO} 2}$ than the types 1,2 and 3 from the olivine-domain veins.

The observed mineral compositions are also broadly consistent with the calculations. Serpentine $\mathrm{X}_{\mathrm{Mg}}$ values are calculated for the appropriate fields (Fig. 16b). Cronstedtite proportions are calculated to be small $(<3 \%$ of an end-member with formula $\left.\left(\mathrm{Mg}_{2} \mathrm{Fe}\right)(\mathrm{FeSi}) \mathrm{O}_{5}(\mathrm{OH})_{4}\right)$, which is consistent with the plotted mineral compositions (Fig. 13). However, it should be noticed that even this small percentage can result in $\mathrm{Fe}^{3+} / \mathrm{Fe}_{\text {tot }}$ values of around $25 \%$ when total $\mathrm{X}_{\mathrm{Fe}}$ is about 0.04 . Brucite $\mathrm{X}_{\mathrm{Mg}}$ values are slightly underestimated. The model predicts that serpentine with an $\mathrm{X}_{\mathrm{Mg}}$ of 0.93 should coexists with brucite with brucite with $\mathrm{X}_{\mathrm{Mg}}=0.77$, while in the type 1 veins brucite coexisting with serpentine with $X_{\mathrm{Mg}}=0.94$ has an $X_{\mathrm{Mg}}$ of $0.80-0.84$ (Fig. 12a),

It would be possible to alter parameters such as pressure, temperature, end-member properties and mixing parameters to obtain a better match between predicted and observed values for the oxygen fugacity of the serpentine-brucite-magnetite assemblage or for $\mathrm{X}_{\mathrm{Mg}}$ of brucite coexisting with serpentine. However, to do so would create a false illusion of the model accuracy, since the pressure and temperature of serpentine formation of these samples, and of the calibration data are poorly known. Instead we 
prefer to consider calculated trends as robust and informative, but treat absolute values with caution. In any case, the good agreement between predicted and observed assemblages and compositional trends suggests that equilibrium held, on some length scales, between serpentine, brucite and magnetite during serpentinization.

The serpentine-only assemblage and the iron-rich serpentine found in the Opx domains suggest that $\mu_{\mathrm{SiO} 2}$ was higher in the Opx domains than in the olivine domains. This is consistent with the higher Si:Mg ratio in Opx than olivine. It also suggests that $\mu_{\mathrm{SiO} 2}$ gradients existed in the sample at some scale less than the millimeters that separate the Opx and olivine domains. An important implication of this observation is that Opx and olivine may not have been at equilibrium with the product phases but, as metastable relicts, they would still have influenced chemical potentials in the vicinity of those relicts.

\subsection{Petrologic implications}

The occurrence of the low variance assemblages, serpentine - brucite and serpentine - brucite - magnetite, which have limited fields of stability, suggests that rockbuffering controlled or strongly influenced $\mu_{\mathrm{SiO} 2}$ and $f \mathrm{O}_{2}$, at least during the formation of type 1 and type 2 veins, a conclusion that was also drawn by Beard et al (2009). $\mu_{\mathrm{SiO} 2}$, in particular, may have varied very little, at least within the olivine domains, so it is likely that this parameter was strongly rock buffered. The assemblage serpentine - brucite magnetite in the rocks is not particularly common, but it is larger than it would have been if there had been no buffering along the univariant line, which further supports the notion of rock-buffering. Such buffering proceeds up $\mathrm{fO}_{2}$ and down $\mu_{\mathrm{SiO} 2}$. 
An increase $\mathrm{fO}_{2}$ of several log units are indicated by the general trend of the sequence of assemblages from type 1 to type 3 veins. This is consistent with an increase in the redox budget (equivalent to ferric iron content) of the rock as the time-integrated fluid-rock ratio increases. Thus, during formation of type 1 veins, $\mathrm{fO}_{2}$ would be rockbuffered to very low values, largely because very little ferric iron is being contributed to the assemblage by the breakdown of olivine. Infiltrating aqueous fluids sourced from the oceans are likely to have been significantly out of redox equilibrium with the serpentinizing rock. Reduction of this fluid can be accommodated by the oxidation of the rock through which it passed. Thus, $f \mathrm{O}_{2}$ is likely to have been somewhat fluid-buffered, but not totally, because in a fully fluid-buffered system the serpentine -- magnetite brucite assemblage would not be observed except in very rarely.

To summarize, the thermodynamic calculations replicate observed assemblages and mineral compositions to an acceptable extent, which suggests that local equilibrium, on some length scale, controlled assemblages and compositions of hydrated minerals. The length scale of this equilibrium was mostly likely less than millimeters, based on differences in mineral compositions and assemblages between olivine and Opx domains. Observed assemblages are consistent with strongly rock-buffered $\mu_{\mathrm{SiO} 2}$, and $\mathrm{fO}_{2}$ that is somewhat rock-buffered, but constantly increasing in response to fluid infiltration and oxidation of the rock by the dissociation of water. Uncertainties remain, particularly with respect to competition between variables such as $\mu_{\mathrm{SiO} 2}$ and bulk $\mathrm{X}_{\mathrm{Mg}}$, and the possibility of iron addition in the Opx domains.

\subsection{Genetic Model}


It is evident from this study and the previous studies of Bach et al. (2006), Beard et al. (2009) and Katayama, et al. (2010) that magnetite is not the initial product of serpentinization, which produces instead relatively iron-enriched brucite and serpentine. Rather it forms somewhat later from the primary brucite and serpentine. Our results provide us with a reasonable model for how this process occurs. The type 1 serpentine veins formed in a rock-dominated system where the availability of $\mathrm{MgO}, \mathrm{FeO}$, and $\mathrm{SiO}_{2}$ was dictated by the composition of the host mineral, olivine or Opx. Oxygen fugacity was poorly buffered to low values on a high variance buffer provided by ferric iron in serpentine.

As serpentinization progressed, the system moved towards a fluid-dominated, system in which the intensive parameters such as oxygen fugacity were determined by the composition of the infiltrating fluid. The silica content was determined by the rate of hydration of nearby Opx and the distance that silica could move before being consumed by the silication of brucite to serpentine (reaction 3). The oxygen fugacity was determined by the extent to which the fluid had equilibrated with the country rock. As indicated by Fig. 16b, the transition from the assemblage brucite-serpentine to brucite-serpentine-magnetite is accompanied by an increase in oxygen fugacity and, perhaps, a minor increase in silica activity. In most rocks, buffering of oxygen fugacity produces no recognizable change in the proportions of minerals in a rock because the amount of oxygen (or hydrogen) in the fluid is so small that extensive buffering may take place with only miniscule changes in mineral abundance. Serpentinization occurs at such low oxygen fugacity, it is one natural process where this is not so. The presence of iron- 
nickel alloys in most serpentinites provides a clue as to the oxygen fugacity under which serpentinization occurs. Although awaruite ( $\gamma^{\prime} \mathrm{Fe}-\mathrm{Ni}$ alloy) with around $25 \% \mathrm{Fe}$ is the most common Fe- alloy found in serpentinites (Frost, 1985), taenite ( $\gamma \mathrm{Fe}-\mathrm{Ni}$ alloy) with up to $40 \% \mathrm{Fe}$ (Botto and Morrison, 1976; Rossetti and Zuchetti, 1988) is not uncommon. Rarely kamacite, an Fe-Ni alloy with more than $95 \%$ Fe has been reported (Sakai and Kuroda, 1983, Rossetti and Zuccetti, 1988). The thermodynamics of the Fe-Ni alloys are geologically unusual because the system Fe-Ni contains an internal phase, awaruite, rather than the solvus found in many silicate systems. A system that has an internal phase must have a negative $\Delta \mathrm{G}$ of mixing, which means that the activity coefficient for $\mathrm{Fe}$ in awaruite must be $<1.0$, which is consistent with the measurements of activitycomposition relations in high-T Fe-Ni alloys (Fraser and Rammensee, 1982). This means that the activity of $\mathrm{Fe}$ in awarite must be higher than 0.25 , which implies that the oxygen fugacity at which serpentinization occurs ranges from the IM buffer to about a log unit above it. (shaded field in Fig. 17).

The mole fraction of $\mathrm{H}_{2}$ produced by the dissociation of water was calculated from the $\Delta \mathrm{G}$ of formation for water taken from the JANAF tables (Dow Chemical, 1971) using activity coefficients calculated from the expressions of Shi and Saxena (1992). Figure 17 shows that, for metamorphism at oxygen fugacities near FMQ, hydrogen makes up vanishingly small amounts of an aqueous fluid so that oxidation-reduction of water provides a very ineffective way to change the redox budget (Evans, 2006) of a rock. However, in serpentinites hydrogen may make up more than $10 \%$ of the aqueous fluid, meaning that oxidation-reduction reactions producing or consuming hydrogen may significantly affect a rock's redox budget. 
In a fluid-dominated system the fluid entering a serpentinite with the assemblage serpentine - brucite, would have a higher oxygen fugacity and a lower hydrogen fugacity than the surrounding serpentinite. Reduction of the fluid is achieved via a multivariant combination of mass-transfer and ion-exchange reactions. One way to describe it is through the following set of reactions:

$$
\begin{aligned}
& 9 \mathrm{Fe}(\mathrm{OH})_{2}+2 \mathrm{SiO}_{2 \text { (aq) }}=2 \mathrm{Fe}_{3} \mathrm{Si}_{2} \mathrm{O}_{5}(\mathrm{OH})_{4}+\mathrm{Fe}_{3} \mathrm{O}_{4}+\mathrm{H}_{2} \\
& \text { in brucite in fluid in serpentine magnetite in fluid } \\
& 6 \mathrm{Fe}(\mathrm{OH})_{2}+\mathrm{O}_{2}=2 \mathrm{Fe}_{3} \mathrm{O}_{4}+2 \mathrm{H}_{2} \mathrm{O} \\
& \text { in brucite in fluid magnetite fluid } \\
& 2 \mathrm{Fe}_{3} \mathrm{Si}_{2} \mathrm{O}_{5}(\mathrm{OH})_{4}+\mathrm{O}_{2}=2 \mathrm{Fe}_{3} \mathrm{O}_{4}+4 \mathrm{SiO}_{2(\text { aq })}+4 \mathrm{H}_{2} \mathrm{O} \\
& \text { in serpentine in fluid magnetite in fluid } \\
& { }_{M_{g F e} e_{1}}^{B r c}=\stackrel{S r p}{M g F e_{1}}
\end{aligned}
$$

where equation (5) is a mass-transfer reaction, equations (6) and (7) are equilibria that balance the chemical potential of oxygen and silica in the system, and equation (8) describes the magnesium-iron exchange equilibrium. Progress along reaction (5) will extract iron from brucite, and, because of the operation of reaction (8), from serpentine as well. Decreasing the activity of the iron end-members of serpentine and brucite will cause oxygen fugacity to rise according to reactions (6) and (7).

Although some of the aqueous silica required for reaction (5) could come from reaction (7), most of it probably would be provided from the fluid, because, as noted by Frost and Beard (2007) the assemblage brucite + serpentine defines one of the lowest silica activities in terrestrial rocks. The stoichiometry of reaction (5) explains the 
common texture of magnetite coring serpentine veins, for it is there that the rock is likely to encounter fluid that is both silica-bearing and out of equilibrium with the oxygen fugacity of the products of olivine hydration

. Figure 17 shows that, for serpentinization in the presence of iron alloys $X_{H_{2}}$ would be equal or greater than 0.1 . This means that, at equilibrium, petrologically significant amounts of magnetite would form from every mole of water that enters the rock. Of course, as reactions (5) and (6) proceed and the serpentine and brucite become more magnesian the buffering reactions between serpentine, brucite, and magnetite will slide to higher oxygen fugacity and lower hydrogen fugacity, making reactions (5) and (6) increasingly less efficient. Thermodynamic modeling (Fig. 16) suggests that changes of $\mathrm{X}_{\mathrm{Mg}}$ for serpentine from 0.93 to 0.96 in the assemblage serpentine-magnetite-brucite will increase oxygen fugacity by about one $\log$ unit. This would decrease $X_{H_{2}}$ by an order of magnitude. This means that the production of magnetite by reaction (5) will become increasingly inefficient as the reaction proceeds. Eventually this would lead to a situation where the oxygen fugacity of the incoming fluid will be buffered over a wide range in oxygen fugacity with only a minimal production of magnetite and the production of magnetite during serpentinization will cease.

Thus, the different vein types in the dunites from New Caledonia record the transition from fluid-dominated to rock-dominated effects of fluid infiltration. Type 1 veins record low time-integrated fluid fluxes and rock buffering, while type 2 and type 3 veins record increasing time-integrated fluid fluxes and increasing degrees of fluid buffering. This model implies that the process of serpentinization involves a complex 
interaction between time, fluid flux, the amount of rock the fluid interacted with during its movement through the system (Fig. 18). The type 3 veins would form in areas of high fluid flux or in areas that were close to the fluid source, whereas type 1 veins would form in distal areas where the fluid flux was low or where the fluids had undergone extensive reaction with fresh serpentinite.

In addition to occurring over time, the transition from fluid-dominated reactions to rock-dominated also can occur spatially. In the core of a vein the silica and oxygen activities may be controlled by the composition of the fluid moving through the vein, but as the fluid moves normal to the flow direction and toward the unaltered olivine, its composition becomes dictated by reactions with the rock. Thus reaction (4), the hydration of olivine to serpentine and Fe-rich brucite, can be taking place on the margin of the vein, while the fluid-dominated reactions (reactions (5-8)) are occurring in the core of the vein, only mm away. This means that during serpentinization brucite will be continually produced on the margins of the type 2 (and maybe even type (3)) veins by the hydration of olivine while it is being consumed in the core of the veins. Because the low oxygen fugacity of serpentinites is caused by reactions (5-8), the low oxygen fugacity of serpentinites could be maintained long after olivine is consumed as long as Fe-rich brucite remains in the rock (as in areas of Figs.6 and 7). The survival of brucite in any serpentinite ultimately reflects the availability of two components, oxygen and silica. If either is in short supply then Mg- or Fe-brucite may persist. Examples of Fe-brucite persisting outside of type 1 veins or other regions of low fluid flow are rare, but see Beard and Hopkinson (2000) for an example. As indicated in sample NC09-11, 
persistence of $\mathrm{Mg}$-rich brucite is fairly common in dunite even in vein interiors (see also Bach et al., 2006).

This model that serpentinization progresses from rock-dominated to fluiddominated explains well the density-susceptibility relations seen in partially serpentinized peridotites, whereby peridotites show a decrease in density (i.e. production of serpentine) before they show an increase in susceptibility (i.e. production of magnetite) (Fig. 19). Each set of data show a different slope on Fig. (19), which suggests that the hydrodynamics of the individual systems control the coupling of the hydration and magnetite-forming reactions. Our model suggests that the different paths followed are caused by different flow regimes attendant during sepentinization. It is evident that large amounts of exotic fluid introduced directly into a peridotite, such as along an active fault, will produce relatively large amounts of magnetite along with serpentinization and hence a steep slope on a density-susceptibility diagram. In contrast fluid that follows a long path through a partially serpentinized peridotite before inducing hydration, perhaps from an area distal from an active fault, will produce relatively little magnetite and a shallow slope on a density-susceptibility diagram.

\subsection{Concluding Remarks}

To conclude, the results of this study indicate that the Fe-bearing capacity of brucite and serpentine is not the controlling factor that stabilizes magnetite, at least in the relatively low temperature system studied here. Instead, magnetite is stabilized by a gradual increase in the redox budget of serpentinizing peridotites, driven by infiltration of a fluid out of redox equilibrium with the host rock. Thus, the precise sequence of mineral 
assemblages developed by any particular part of the rock is determined by its timeintegrated fluid infiltration history, and the complex interplay between fluid infiltration and the transport of elements, such as iron and silica, between domains within the rock. The preservation of these complex mineral assemblages, combined with relative simplicity of the chemical system, provides excellent examples of limited-length-scale equilibrium. Complementary thermodynamic modeling can be used to construct maps of chemical potential variation and solute transport on a sub-thin section scale. Such detailed work has the potential to contribute significantly to our knowledge of the serpentinization process as well as the mechanisms of fluid infiltration and rock alteration.

\section{Acknowledgements}

$\mathrm{KE}$ and BRF gratefully acknowledge support for this research from the Australian Research Council Discovery grant DP1090475. KE also acknowledges support from a Curtin Research and Teaching Fellowship. This is TiGer publication number (number will be added when paper is accepted). We also thank Roger Powell for helpful discussions on this topic. 


\section{Captions}

Figure. 1. Geologic map of the geology of New Caledonia. Modified after Cluzel et al. (2001). Star gives location of samples used in this study.

Figure 2: Image of the full thin section from sample NC09-05C. Locations of Opx are outlined, the rest of the sample consists of partially serpentinized olivine and chromite. Boxes show areas studied in detail and shown in Figure 4.

Figure 3: Image of a portion of the thin section from sample NC09-11 showing a cmwide vein of serpentine in dunite. Box with solid lines shows area where 380 points were analyzed. Box with dashed lines shows the location of BSE and X-ray images shown in Fig. 8.

Figure 4: Photomicrographs of areas from NC09-05C. Boxes show areas from which probe analyses were obtained. a. Area 1, type 1 and type 2 serpentine veins cutting olivine. b Area 2, large type 2 serpentine vein. c. two types of serpentine veins cutting Opx.

Figure 5: Backscattered electron (BSE) image and X-Ray element maps of the Type 1 vein, from NCO9-05C (see Fig. 4a). Box in BSE figure shows the area from which 121 point analyses were obtained. Abbreviations are from Kretz (1983).

Figure 6: BSE and X-Ray element maps of the small type 2 veins (Fig. 4a), NC09-05. Field of view shows the area from which 121 point analyses were obtained.

Figure 7: BSE and element maps for large type 2 vein in area 2, NC09-5 area 2 (Fig. 4b). White box in the SEM image gives area from which 99 point analyses were obtained.

Figure 8: BSE and element maps for core of type 3 veins in sample NC09-11. See Figure 3 for relative location.

Figure 9: BSE and element maps for yellow vein cutting opx in Fig. 4c. NC09-05C. White polygon is area from which 143 point analyses were made. See Figure 2 for relative location.

Figure 10: BSE and element maps for green vein cutting opx in Fig. 4c. White rectangle shows area from which 165 point analyses were made. NC09-05C. See Figure 2 for relative location.

Figure 11: Plot of silica cations versus $\mathrm{Fe}+\mathrm{Mg}$ cations in serpentine veins. a. Type 1 vein from NC09-5 in area shown in Figure 5a. b. Type 2 veins from NC09-5 in area shown in Figure 5b. c. Large type 2 veins from NC09-5 in area in Figure 5c. d. cm-wide vein from Sample NC09-11. e. Vein in Opx from sample NC09-5 in area 
shown in Figure 5d. f. Vein in Opx from sample NC09-5 in area shown in Figure $5 \mathrm{~d}$.

Figure 12: Plot of $\mathrm{X}_{\mathrm{Mg}}$ versus $\mathrm{Si}$ atoms for serpentine veins.

Figure 13: Plot of Fe versus $\mathrm{Si}+\mathrm{Al} / 2$ for serpentine. Cronstedtite substitution trend after Evans (2008).

Figure. 14: Plot of $X_{M g}$ in brucite against $X_{M g}$ in serpentine. Shaded field gives values from Evans and Tromsdorff (1975) and Peretti (1988). Filled circles give the compositions reported in this study. Lines give $\mathrm{Kd}$ values for the exchange of $\mathrm{Fe}$ and $\mathrm{Mg}$ between olivine and serpentine. Heavy line is the Kd suggested by Evans and Trommsdorff.

Figure 15: Isocon diagrams showing the mobility of oxides during the alteration of olivine and Opx. a. Type 1 vein shown in Fig 3a, 4a. Boxes with dashed outlines show where oxides would plot if the average analysis contained $20 \%$ less brucite. $b$. Type 2 veins shown in Fig. 3a, 4b. c. Type 2 vein shown in Fig. 3b, 4c. d. large veins showing in Fig. 2, boxes with dashed outlines show where oxides would plot if $2 \%$ magnetite were added. d. serpentine veins in Opx shown in Fig. 3c, 4d. Dashed reference lines show line of conserved $\mathrm{Al}_{2} \mathrm{O}_{3}$. e. serpentine vein in Opx

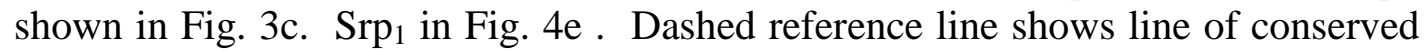
$\mathrm{Al}_{2} \mathrm{O}_{3}$.

Figure 16: Phase diagrams showing the stability of assemblages in serpentinites. Pseudosection showing P-T relations for a rock with the composition of the New Caledonia ophiolite (see inset for composition). Effect of the chemical potentials of silica and oxygen on the stability of mineral assemblage in serpentinites at $200^{\circ} \mathrm{C}$ and $1 \mathrm{kbar}$ assuming that $\mathrm{X}_{\mathrm{Mg}}$ of serpentine is 0.9 . Light lines show the stabilities of the FMQ and the IM buffer for an activity of Fe in the alloy $=0.25$. Shaded ovals give the relative stabilities of type 1, 2, and 3 veins in olivine and the veins cutting Opx.

Figure 17: phase diagram showing the mole fraction of hydrogen in water as a function of oxygen fugacity relative to FMQ. Heavy line shows the IM buffer and shaded area gives the conditions where iron-nickel alloys are likely to be stable.

Figure 18: Sketch showing the possible relation between type 1, 2, and 3 serpentine veins. Type 1 veins being rock-dominate lie distal from any water source, whereas type 2 and 3 are fluid-dominated and lie more proximal to the source. Colorless $=$ peridotites, gray $=$ serpentine + brucite, black $=$ magnetite .

Figure 19: density versus susceptibility of partially serpentinized peridotites compared to the trend expected if the formation of serpentine and magnetite were coupled. Data from Toft et al., 1990, Oufi, et al., 2002, Bach et al., 2006, and Beard et al., 2009. 


\section{References}

Aitchison, J.C., Clarke, G.L., Meffre, S., Cluzel, D., 1995. Eocene arc-continent collision in New Caledonia and implications for regional southwest Pacific tectonic evolution. Geology 23, 161-164.

Anderson, D.J., Lindsley, D.H., Davidson, P.M., 1993. QUILF: a Pascal program to assess equilibria among $\mathrm{Fe}-\mathrm{Mg}-\mathrm{Ti}$ oxides, pyroxenes, olivine, and quartz. Computers and Geosciences 19, 1333-1350.

Bach, W., Paulick, H., Garrido, C.J., Ildefonse, B., Meurer, W.P., Humphris, S.E., 2006. Unraveling the sequence of serpentinization reactions: petrography, mineral chemistry, and petrophysics of serpentinites from MAR $15^{\circ} \mathrm{N}$ (ODP Let 209, Site 1274). Geophysical Research Letters 33, doi 10.1029/2006GL025681/

Baldwin, S.L., Rawling, T.J., Fitzgerald, P.G., 2007. Thermochronology of the New Caledonia high-pressure terrane: Implications for middle Tertiary plate boundary processes in the southwest Pacific, in Cloos, M., Carlson, W.D., Gilbert, M.C., Liou, J.G., Sorensen, S.S. (Eds.), Convergent Margin Terranes and Associated Regions: A Tribute to W.G. Ernst: Geological Society of America Special Paper 419, 117-134,

Beard, J.S., Frost, B.R., Fryer, P., McCaig, A., Searle, R., Ildefonse, B., Zinin, P., Sharma, S.K., 2009. Onset and progression of serpentinization and magnetite formation in olivine-rich troctolites from IOCP Hole U1309D. Journal of Petrology 50, 387-403.

Beard, J.S. Hopkinson, L., 2000. A fossil, serpentinization-related hydrothermal vent, Ocean Drilling Program Leg 173, Site 1068 (Iberia Abyssal Plain): Some aspects of mineral and fluid chemistry. Journal of Geophysical Research 105, 1652716540.

Botto, R.I., and Morrison, G.H., 1976, Josephinite: A unique nickel-iron. American Journal of Science 276, 241-274.

Charlou, J.L., Donval, J.P., Fouquet, Y., Jean-Baptiste, P. Holm, N., 2002. Geochemistry of high $\mathrm{H}_{2}$ and $\mathrm{CH}_{4}$ vent fluids issuing from ultramafic rocks at the Rainbow hydrothermal field, (36814'N,MAR). Chemical Geology 191, 345-359.

Clarke, G.L., Aitchison, J.C., Cluzel, D., 1997. Eclogites and blueschists of the Pam Peninsula, NE New Caledonia: a reappraisal. Journal of Petrology 38, 943-976.

Cluzel, D., Aitchison, J.C., Picard, C., 2001. Tectonic accretion and underplating of mafic terranes in the Late Eocene intraoceanic fore-arc of New Caledonia (Southwest Pacific): geodynamic implications. Tectonophysics 340, 23 - 59

Cluzel, D., Meffre, S., Maurizot, P., Crawford, A.J., 2006 Earliest Eocene (53 Ma) convergence in the southwest Pacific: Evidence from pre-obduction dikes in the ophiolite of New Caledonia. Terra Nova 18, 395-402.

D'Antonio, M., Kristensen, M.B., 2004. Serpentine and brucite of ultramafic clasts from the South Chamorro Seamount (Ocean Drilling Program Leg 195, Site 1200): inferences for the serpentinization of the Mariana fore arc mantle. Mineralogical Magazine 68, 887-904.

Deer, W.A., Howie, R.A., Zussman, J., 1962. Rock Forming Minerals, vol. 5 Non silicates, Longmans, London.

Dow Chemical Co., 1971. JANAF thermodynamic tables. Washington DC., United States 
Bureau of Standards.

Evans, B.W., 2008. Control of the products of serpentinization by the $\mathrm{Fe}^{2+} \mathrm{Mg}_{-1}$ exchange potential of olivine and orthopyroxene. Journal of Petrology 49, 1873-1887.

Evans, B.W., Kuehner, S.M., Chopelas, A., 2009. Magnetite-free, yellow lizardite serpentinization of olivine websterite, Canyon Mountain complex, N.E. Oregon. American Mineralogist 94, 1731-1734.

Evans, B.W., Tromsdorff, V., 1972. Der Einfluss des Eisens auf die Hydratisierung von Duniten. Schweizerische Mineralogische und Petrographische Mittielunger 52, $251-256$.

Evans, K.A., 2006. Redox decoupling and redox budgets: Conceptual tools for the study of earth systems. Geology 34, 489-492.

Evans, K.A., 2012. The redox budget of subduction zones. Earth Science Reviews 113, 11-32.

Fraser. D.G., Rammensee, W., 1982, Activity measurements by Kundsen cell mass spectrometry - the system Fe-Co-Ni and implications for condensation processes in the solar nebula. Geochimica Cosmochica Acta 46, 549-556.

Frost, B.R., 1985, On the stability of sulfides, oxides, and native metals in serpentinite. Journal of Petrology 26, $31-62$.

Frost, B.R., Beard, J.S., 2007. On silica activity and serpentinization. Journal of Petrology 48, 1351-1368.

Grant, J.A., 1986. The isocon diagram - A simple solution to Gresens' equation for metasomatic alteration. Economic Geology 81, 1976-1982.

Groppo, C., Rinaudo, C., Cairo, S., Gastaldi, D., 2006. Micro-Raman spectroscopy for a quick and reliable identification of serpentine minerals from ultramafics. European Journal of Mineralogy 18, 319-329.

Holland, T.J.B., Powell, R., 2011. An improved and extended internally consistent thermodynamic dataset for phases of petrological interest, involving a new equation of state for solids. Journal of Metamorphic Geology 29, 333-383.

Hostetler, R.B., Coleman, R.G., Mumpton, F.A., Evans, B.W., 1966. Brucite in Alpine serpentinites. American Mineralogist 51, 75-98.

Katayama, I., Kurosaki, I., Hirauchi, K., 2010. Low silica activity for hydrogen generation during serpentinization: An example of natural serpentinites in the Mineoka ophiolite complex, central Japan. Earth and Planetary Science Letters 298, 199-204.

Kelemen, P.B., Matter, J.M., 2009. In situ carbonation of peridotites for $\mathrm{CO}_{2}$ storage. Proceedings of the National Academy of Sciences 105, 17295-17300.

Kelley, D.S., Karson, J.A., Blackman, D.K., Früh-Green, G.L., Butterfield, D.A., Lilley, M.D., Olson, E.J., Schrenk, M.O., Roe, K.K., Lebon, G.T. Rivizzigno, P., 2001. An off-axis hydrothermal vent field near the Mid-Atlantic Ridge at 30. Nature, 412, 145-149.

Kretz, R., 1983, Symbols for rock-forming minerals. American Mineralogist, 68, 277 279.

Lagabrielle, Y., Maurizot, P., Lafoy, Y., Cabioch, G., Pelletier, B., Regnier, M., Wabete, I., Calmant, S., 2005. Post-Eocene extensional tectonics in southern New Caledonia (SW Pacific): Insights from onshore fault analysis and offshore seismic data: Tectonophysics 403, 1-28. 
O'Hanley, D.S., Dyar, M.D., 1993. The composition of lizardite 1T and the formation of magnetite in serpentinites. American Mineralogist 78, 391-404.

O'Hanley, D.S., Dyar, M.D., 1998. The composition of chrysotile and its relationship with lizardite. Canadian Mineralogist 36, 727-739.

Oufi, O., Cannat, M., Horen, H., 2002. Magnetic properties of variably serpentinized abyssal peridotites. Journal of Geophysical Research 107, 2095-2114.

Padron-Navarta, Jose Alberto; Lopez Sanchez-Vizcaino, Vicente; Garrido, Carlos J; Gomez-Pugnaire, Maria Teresa., 2011, Metamorphic Record of High-pressure Dehydration of Antigorite Serpentinite to Chlorite Harzburgite in a Subduction Setting (Cerro del Almirez, Nevado-Filabride Complex, Southern Spain), Journal of Petrology52, 2047-2078.

Peretti, A., 1988. Occurrence and Stabilities of Opaque Minerals in the Malenco Serpentinite (Sondrio, Northern Italy). Ph.D. dissertation, Swiss Federal Institute of Technology, Zürich.

Powell, R., Holland, T., Worley, B., 1998. Calculating phase diagrams involving solid solutions via non-linear equations, with examples using THERMOCALC. Journal of Metamorphic Geology 16, 577-588.

Rawling, T.J., Lister, G.S., 2002. Large-scale structure of the eclogite-blueschist belt of New Caledonia. Journal of Structural Geology 24, 1239-1258

Rossetti, P. and Zucchetti, S., 1988, The occurrence of native iron, Fe-Co and Ni-Fe alloys from the Balangero asbestos mine (Western Italian Alps). Ophioliti, 13, 4356.

Russell, M. J., Arndt, N. T., 2005. Geodynamic and metabolic cycles in the Hadean. Biogeosciences, 2, 97-111.

Russell, M.J., Hall, A.J., 1997. The emergence of life from iron monosulfide bubbles at a submarine hydrothermal redox and $\mathrm{pH}$ front. Journal of the Geological Society of London 154. 377-402.

Sakai, K. and Yoshimasu, K., 1983, Native iron and the associated minerals from the uttramafic masses in the Sanbagawa belt, central Japan. Journal of the Japanese Association of Mineralogists, Petrologists, and Economic Geologists, 78, 467478.

Schroeder, T., John, B., Frost, B.R., 2002, Geologic implications of seawater circulation through peridotite exposed as slow-spreading mid-ocean ridges. Geology, 30, 367-370.

Shervais, J.W., Kolesar, P., Andreasen, K., 2005. A field and chemical study of serpentinization - Stonyford, California: Chemical flux and mass balance. International Geology Review 47, 1-23.

Shi, P., Saxena, S.K., 1991. Thermodynamic modeling of the C-H-O-S fluid system. American Mineralogist 77, 1038-1049.

Sleep, N.H., Meibom, A., Fridriksson, Th., Coleman, R. G., Bird, D. K., 2004. H2-rich fluids from serpentinization: Geochemical and biotic implications. Proceedings of the National Academy of Sciences of the USA 101, 12818-12823.

Spandler, C., Rubatto, D., Hermann, J., 2005. Late Cretaceous - Tertiary tectonics of the Southwest Pacific; insights from $\mathrm{U}-\mathrm{Pb}$ sensitive high-resolution ion microprobe (SHRIMP) dating of eclogite facies rocks from New Caledonia. Tectonics 24, DOI 10.1029/2004TC001709. 
Titus, S.J., Maes, S.M., Benford, B., Ferré, E.C., Tikoff, B., 2011. Fabric development in the mantle section of a paleo-transform fault and it effect on ophiolite obduction, New Caledonia. Lithosphere 3, 221-244.

Toft, P.B., Arkanai-Hamed, J., Haggerty, S.E., 1990, The effects of serpentinization on density and magnetic susceptibility: a petro-physical model. Physics of the Earth and Planetary Interiors 65, 137-157.

Vils, F., Pelletier, L., Kalt, A., Muntener, O., Ludwig, T., 2008. The Lithium, Boron and Beryllium content of serpentinized peridotites from ODP Leg 209 (Sites 1272A and 1274A): Implications for lithium and boron budgets of oceanic lithosphere. Geochimica et Cosmochimica Acta 72, 5475-5504. 


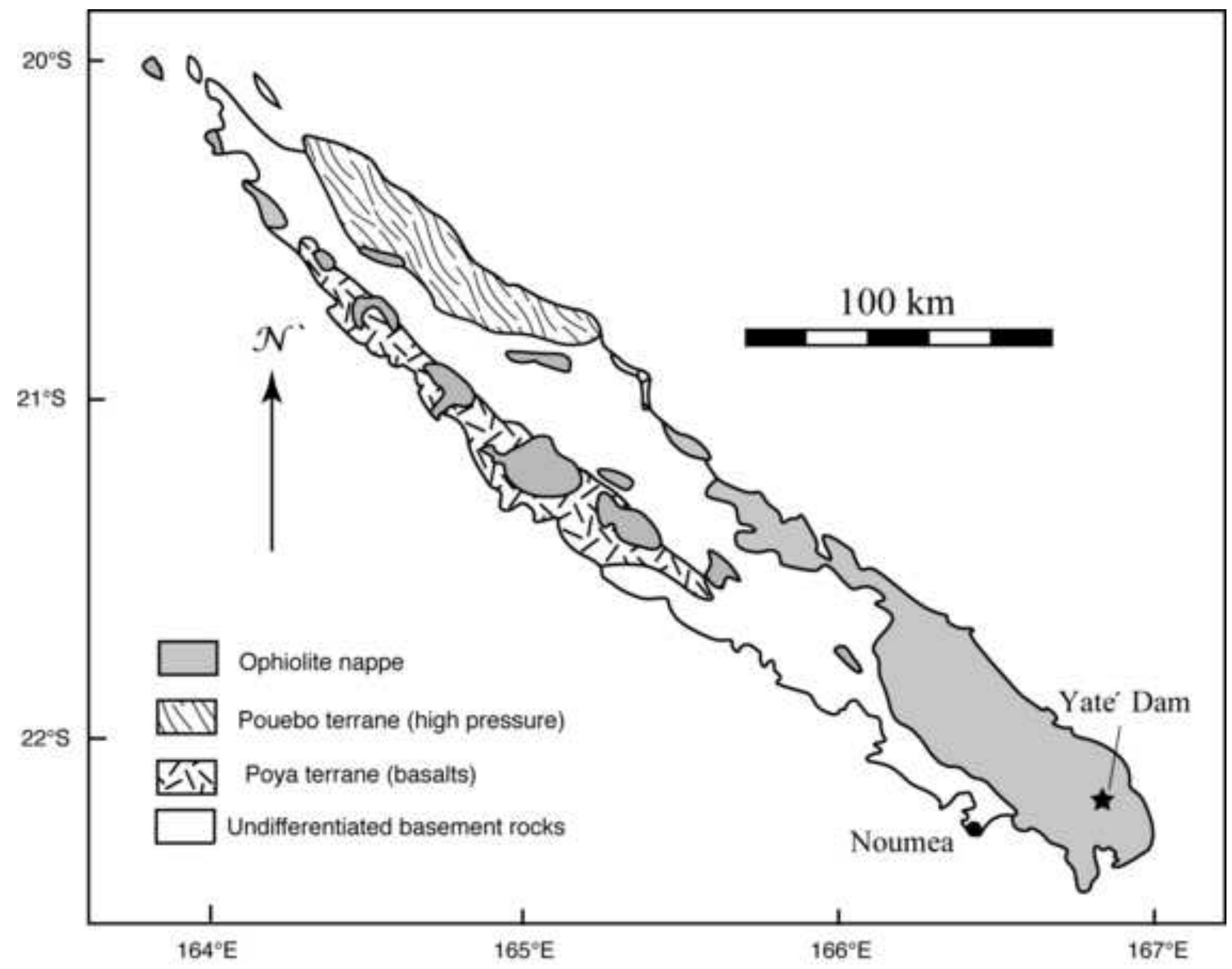

Frost et al. Fig. 1 


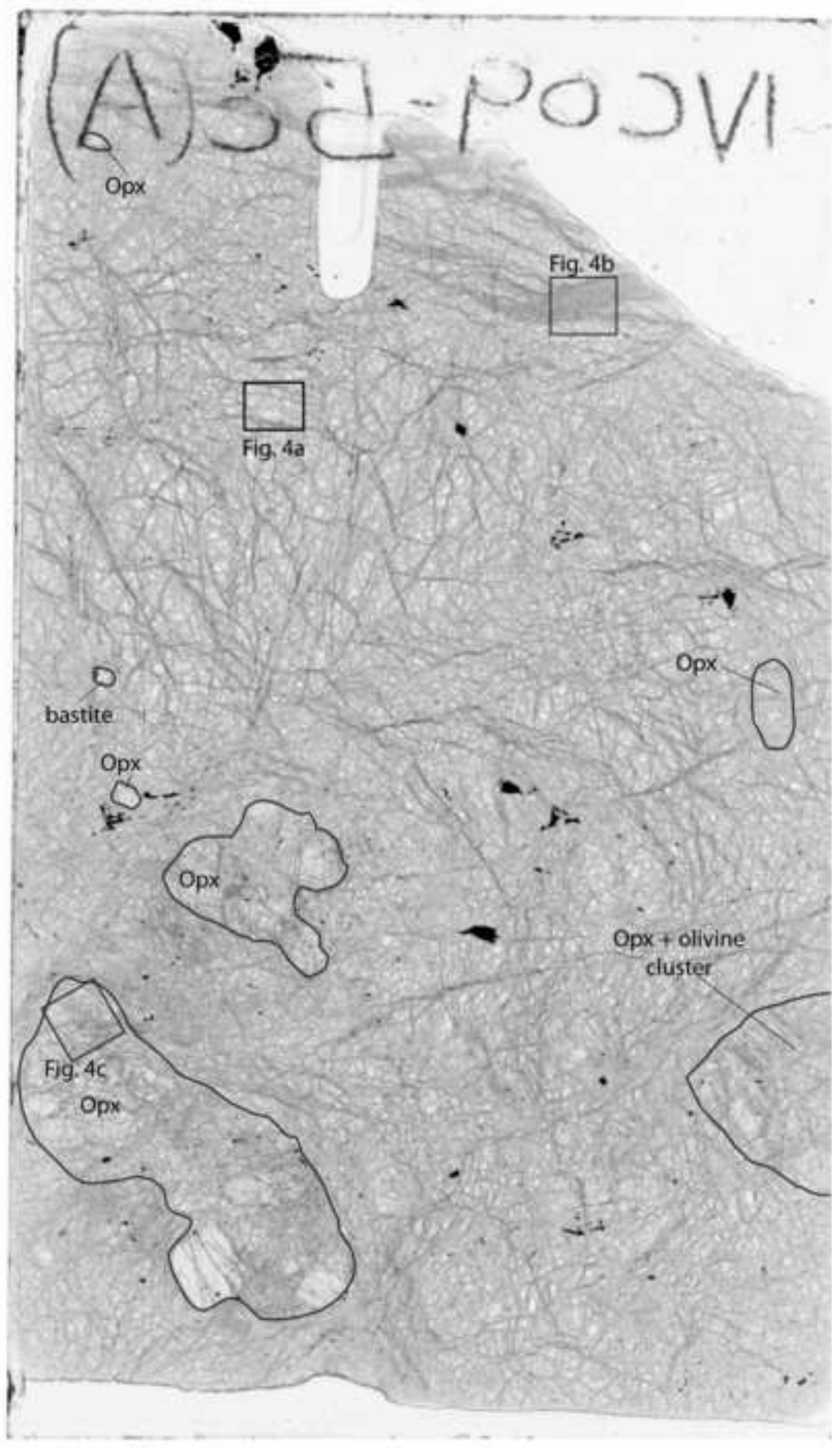

Frost et af., Fig.2 


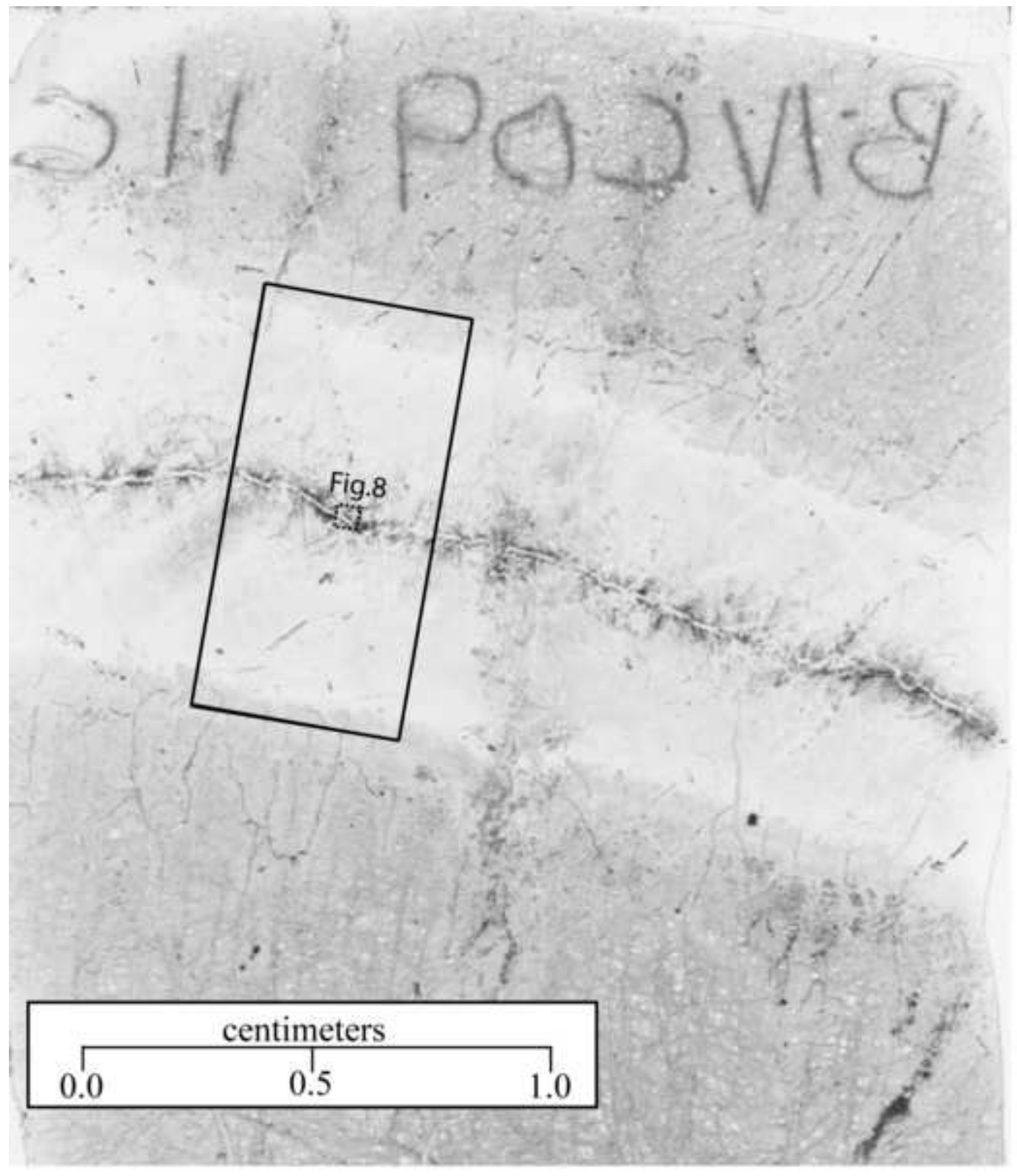

Frost et af, Fig. 3 

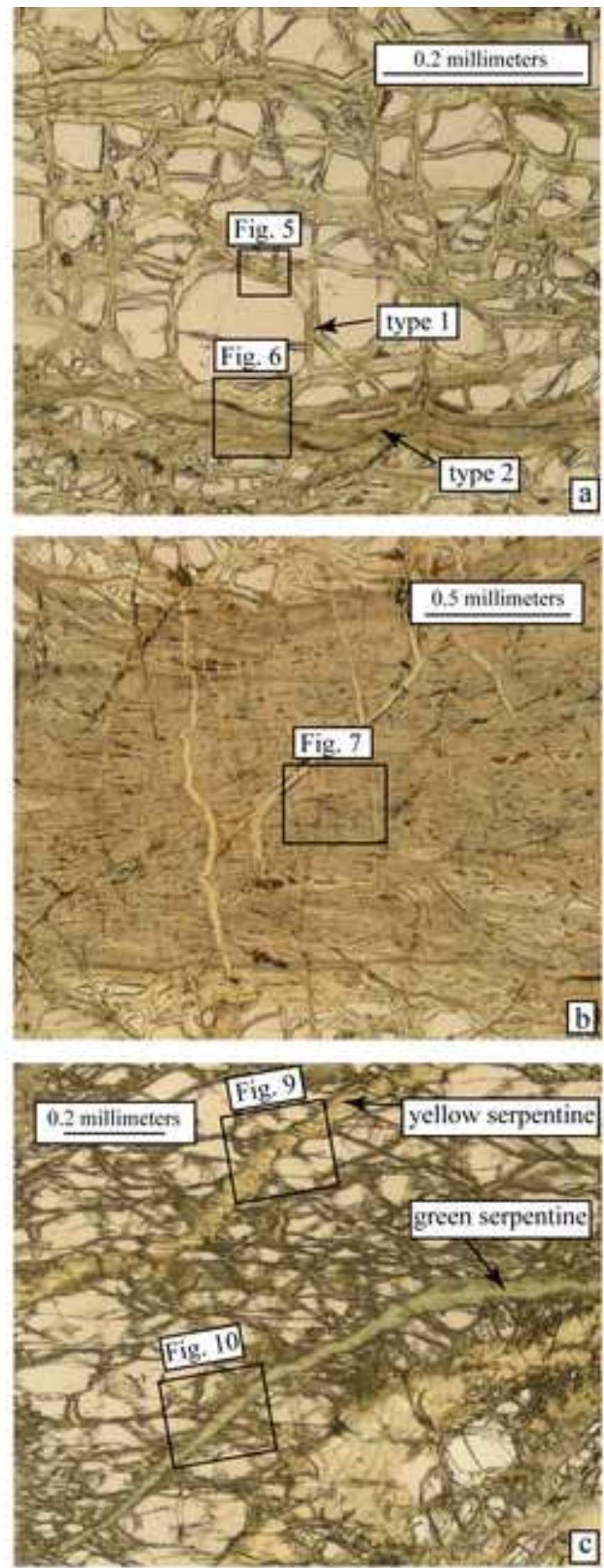

Frost et af., FIg. 4 

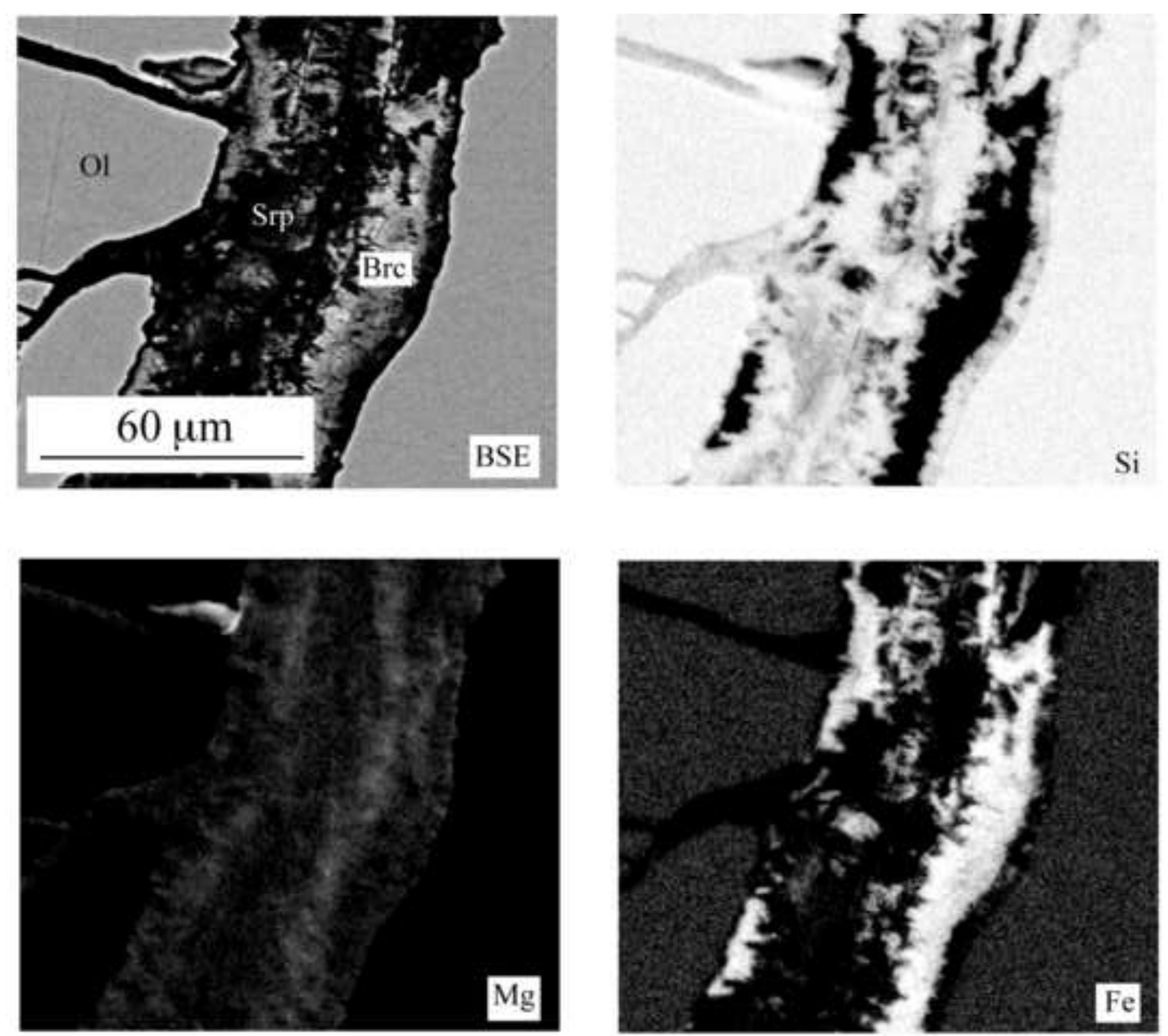

Frost et al., Fig. 5 

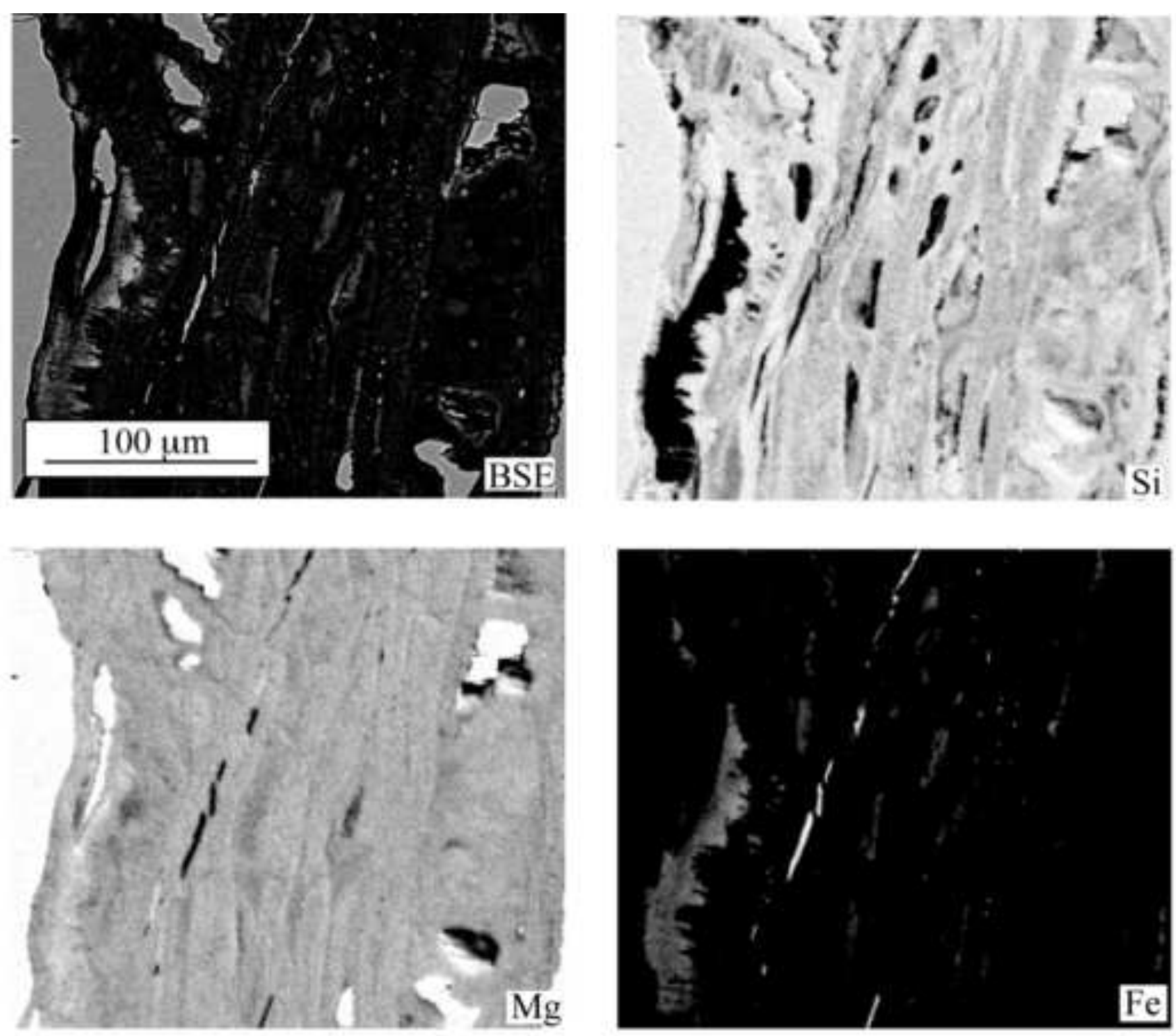

Frost et al. Fig. 6 

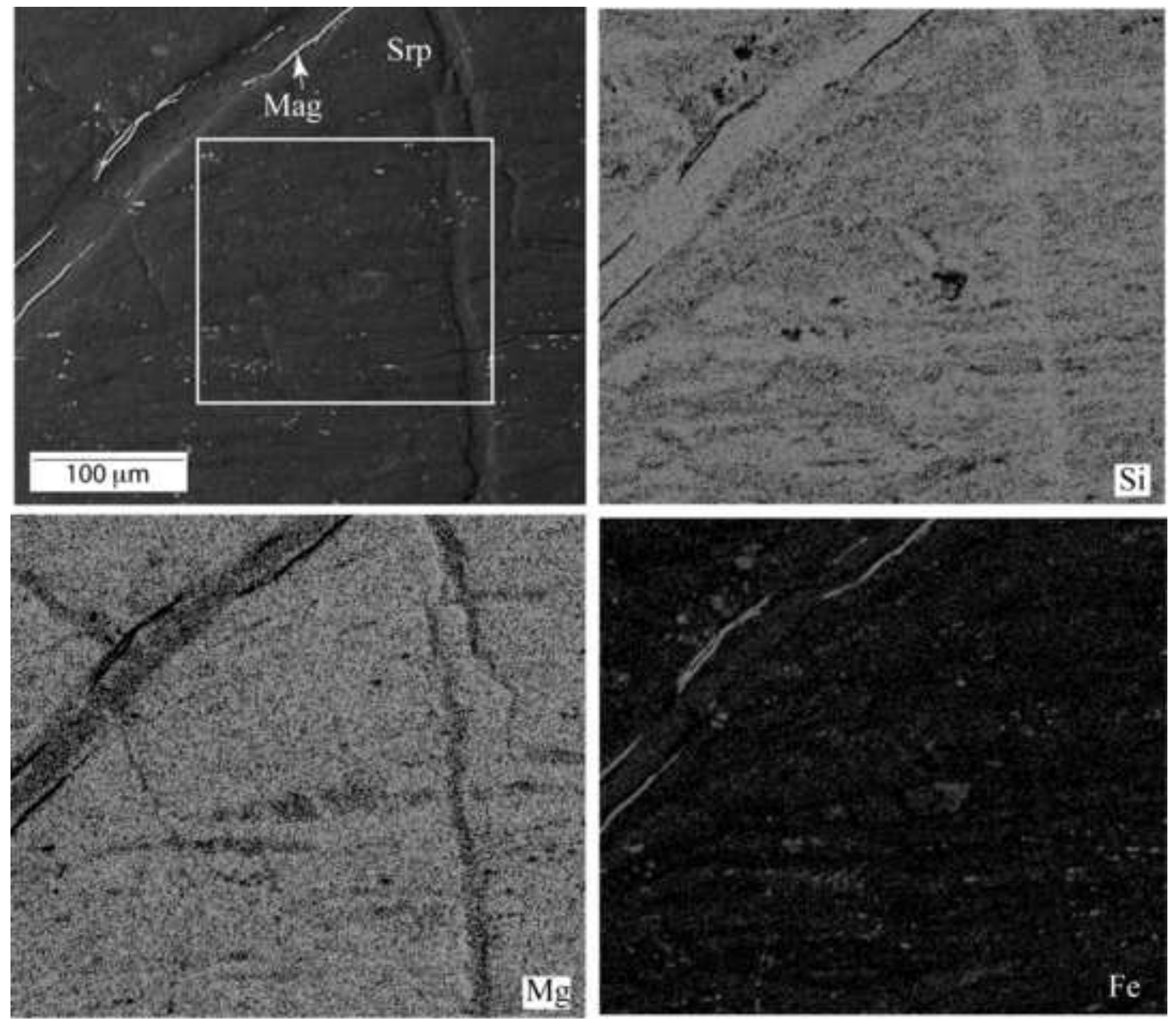

Frost et al., Fig. 7 

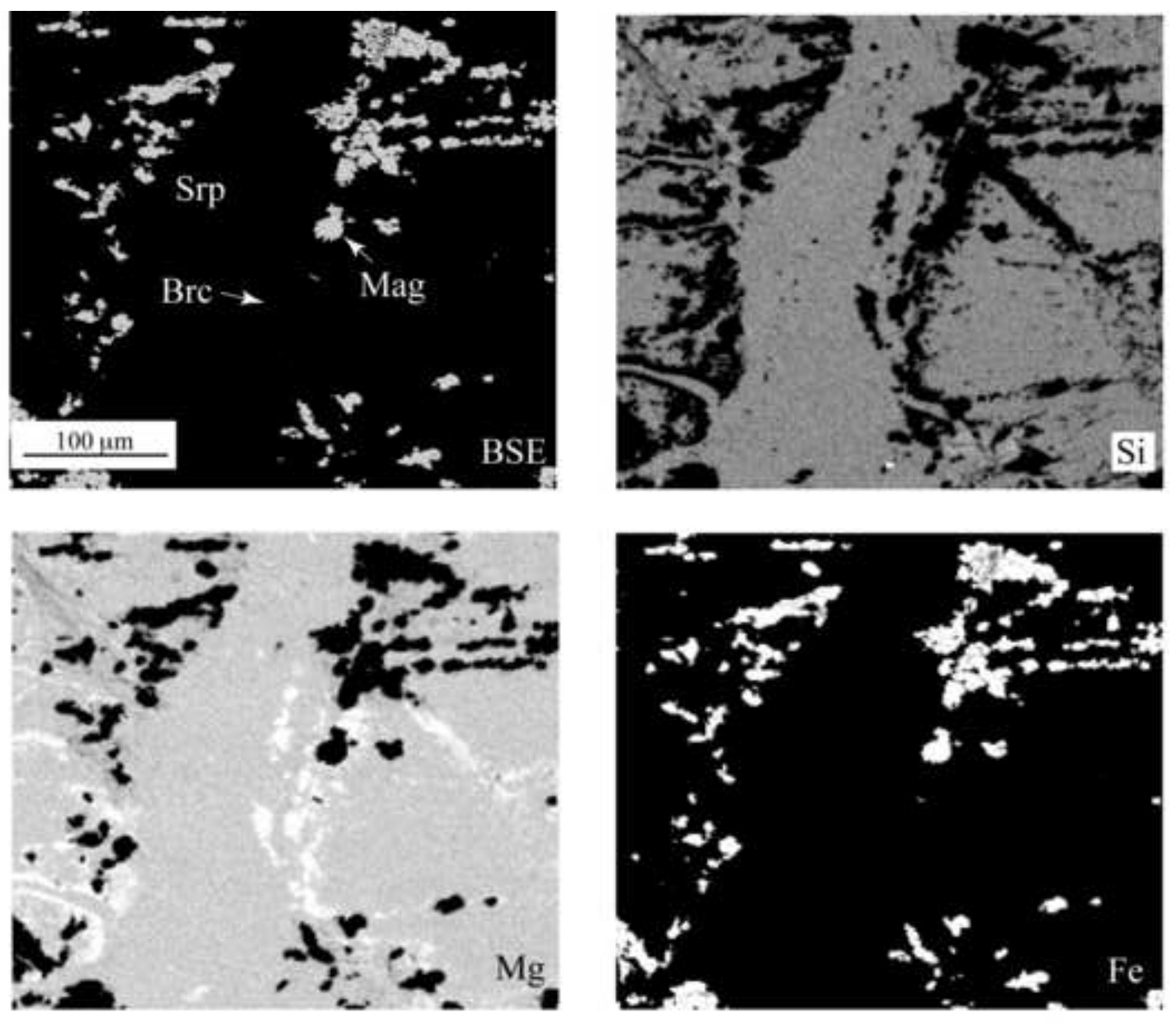

Frost et al. Fig. 8 

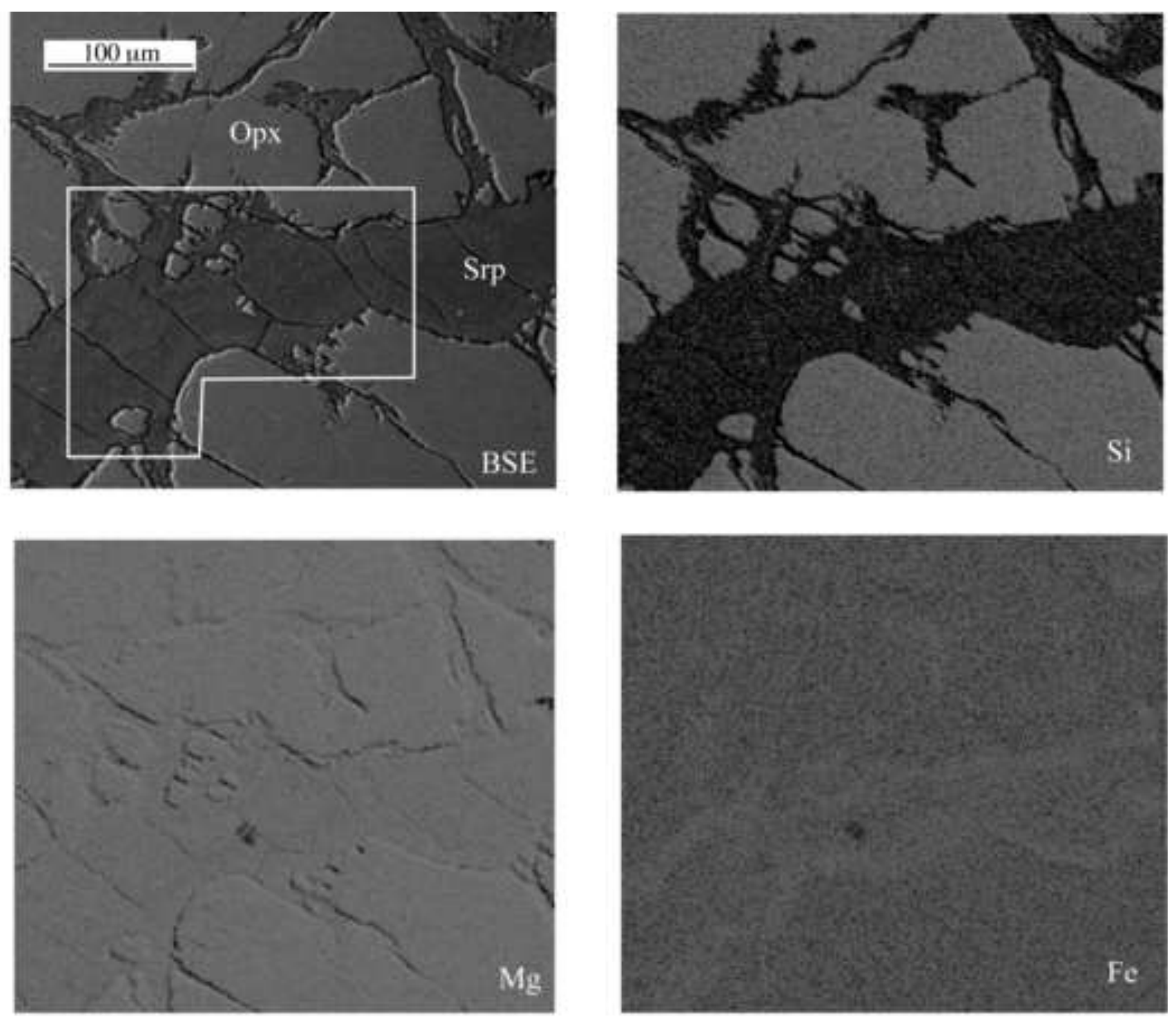

Frost et al., Fig. 9 

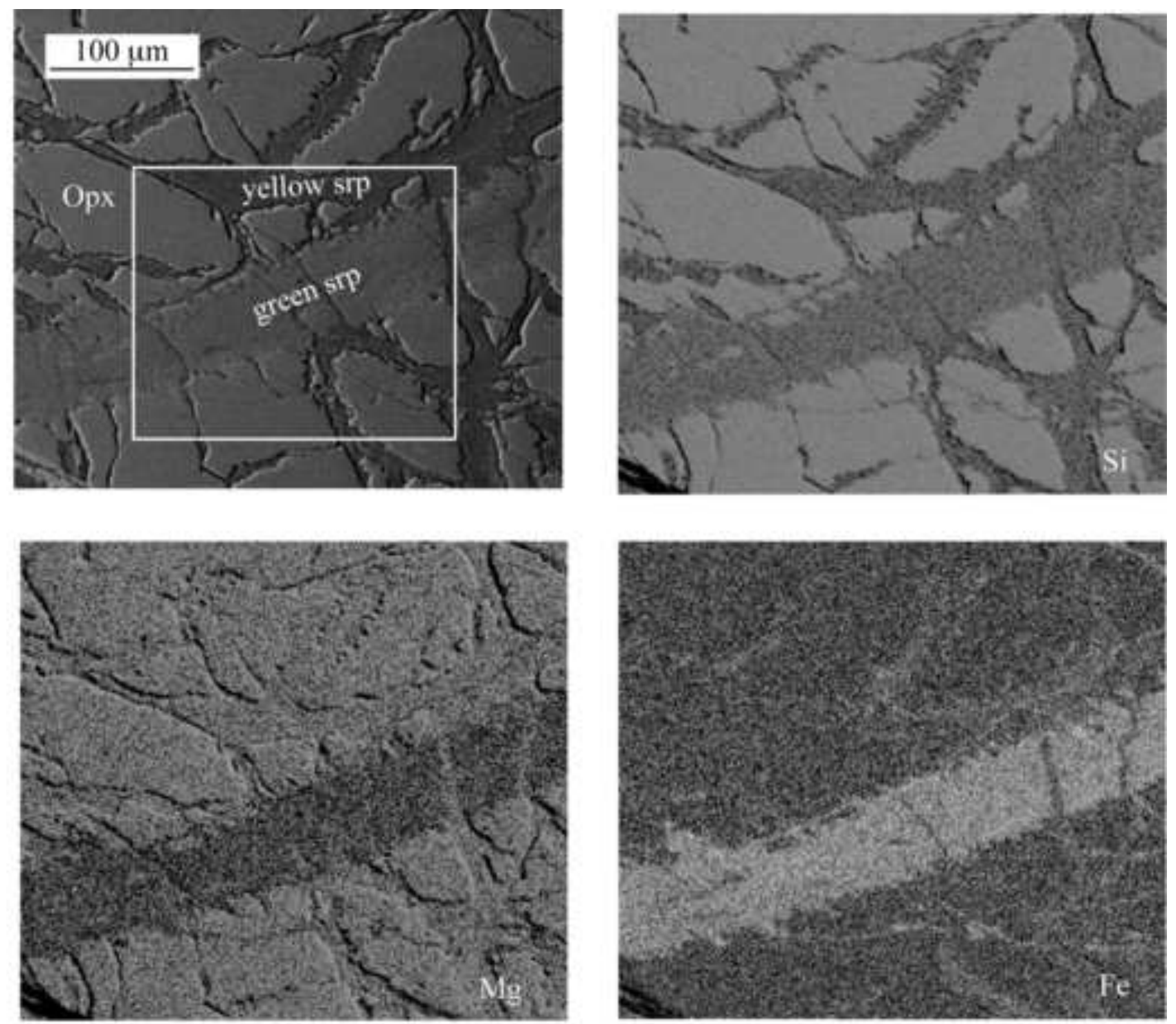

Frost et al., Fig. 10 

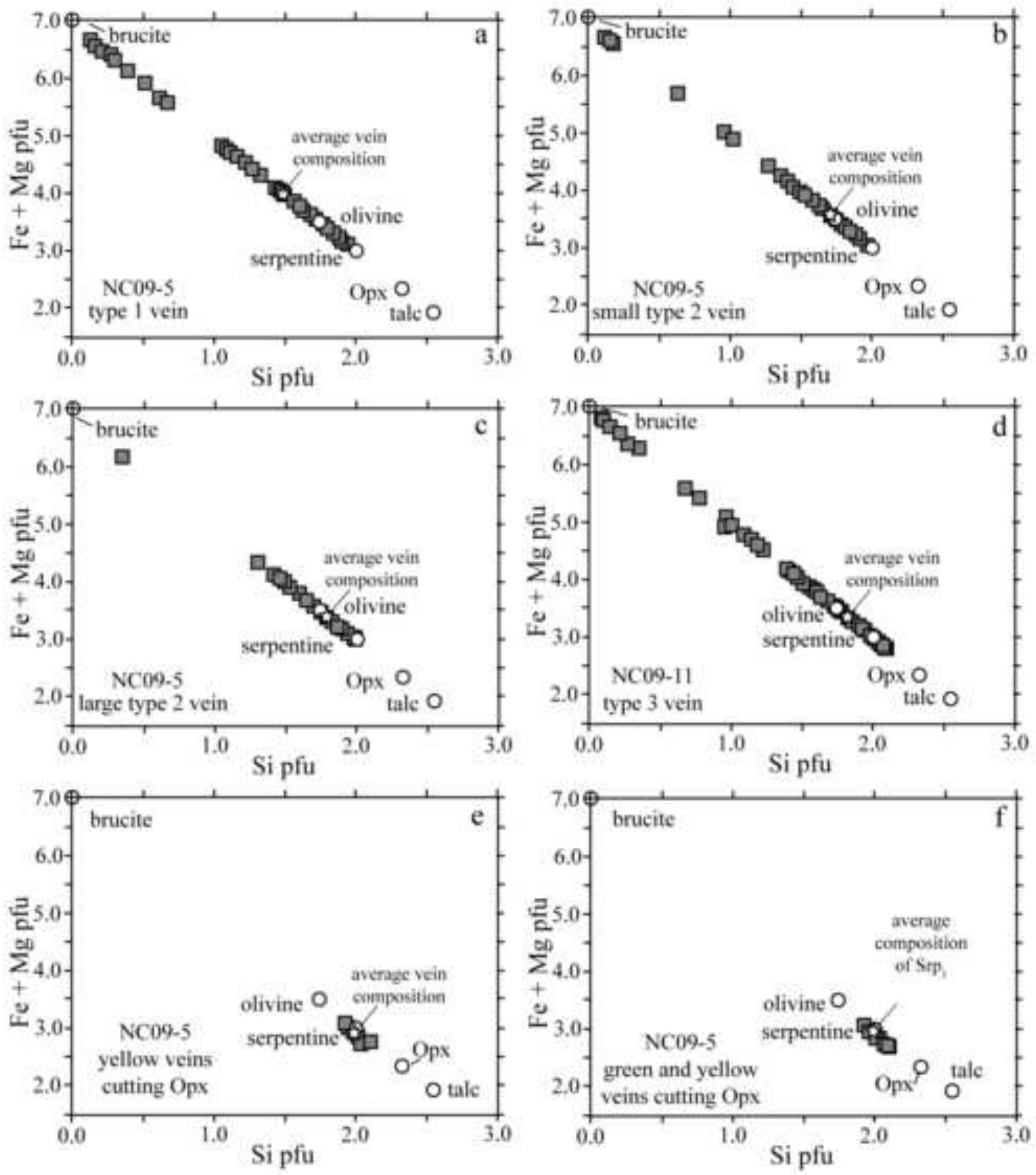

Frost et af, Fig. $n$ 

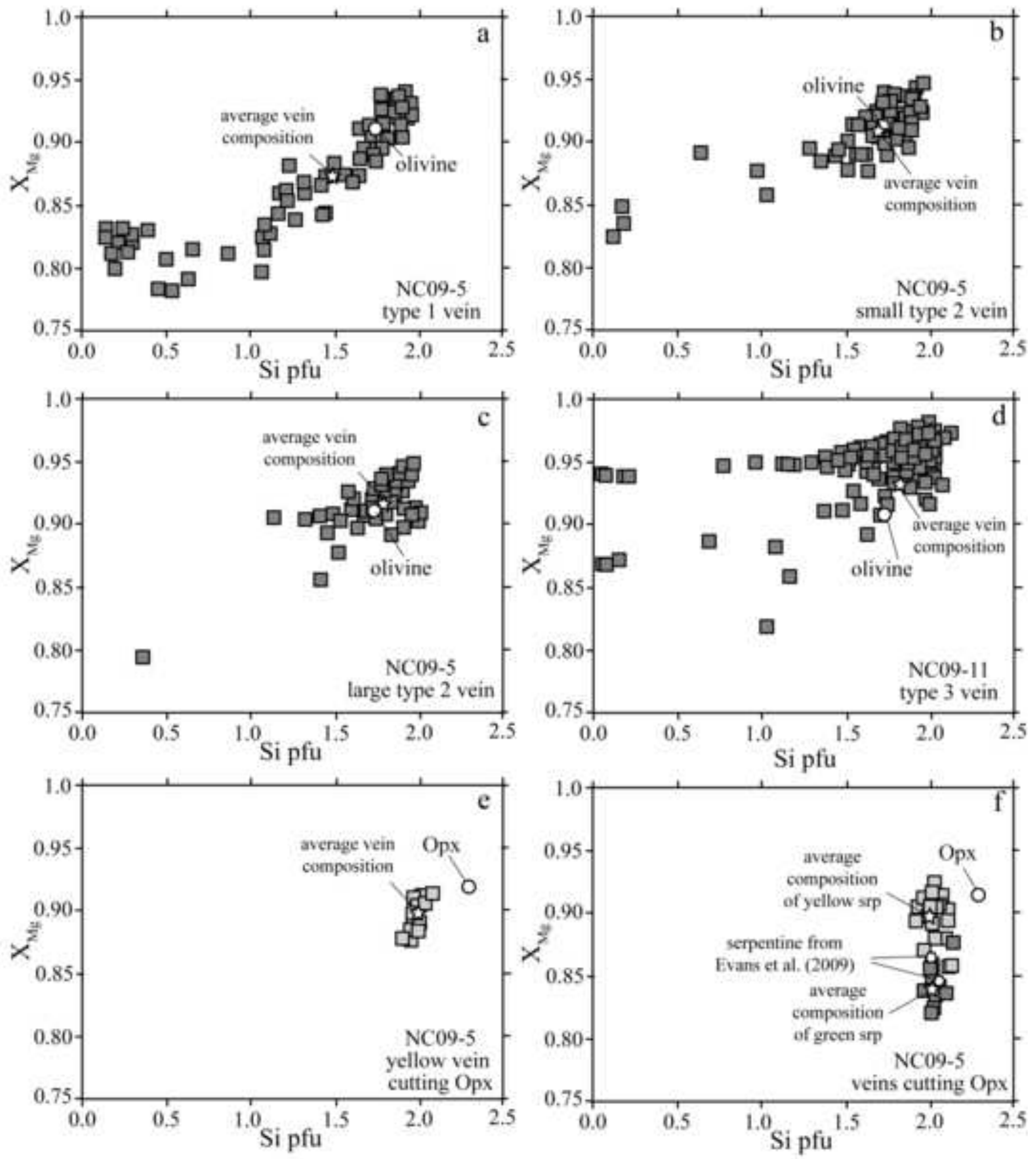

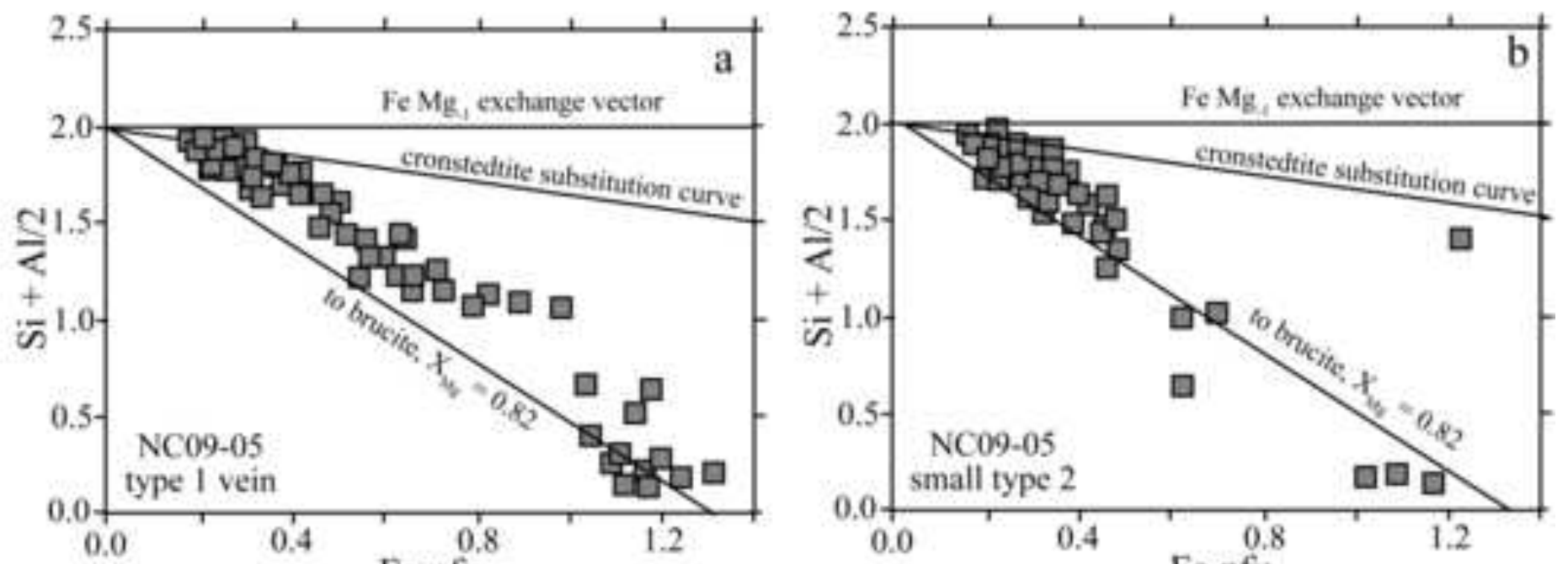

Fe pfu
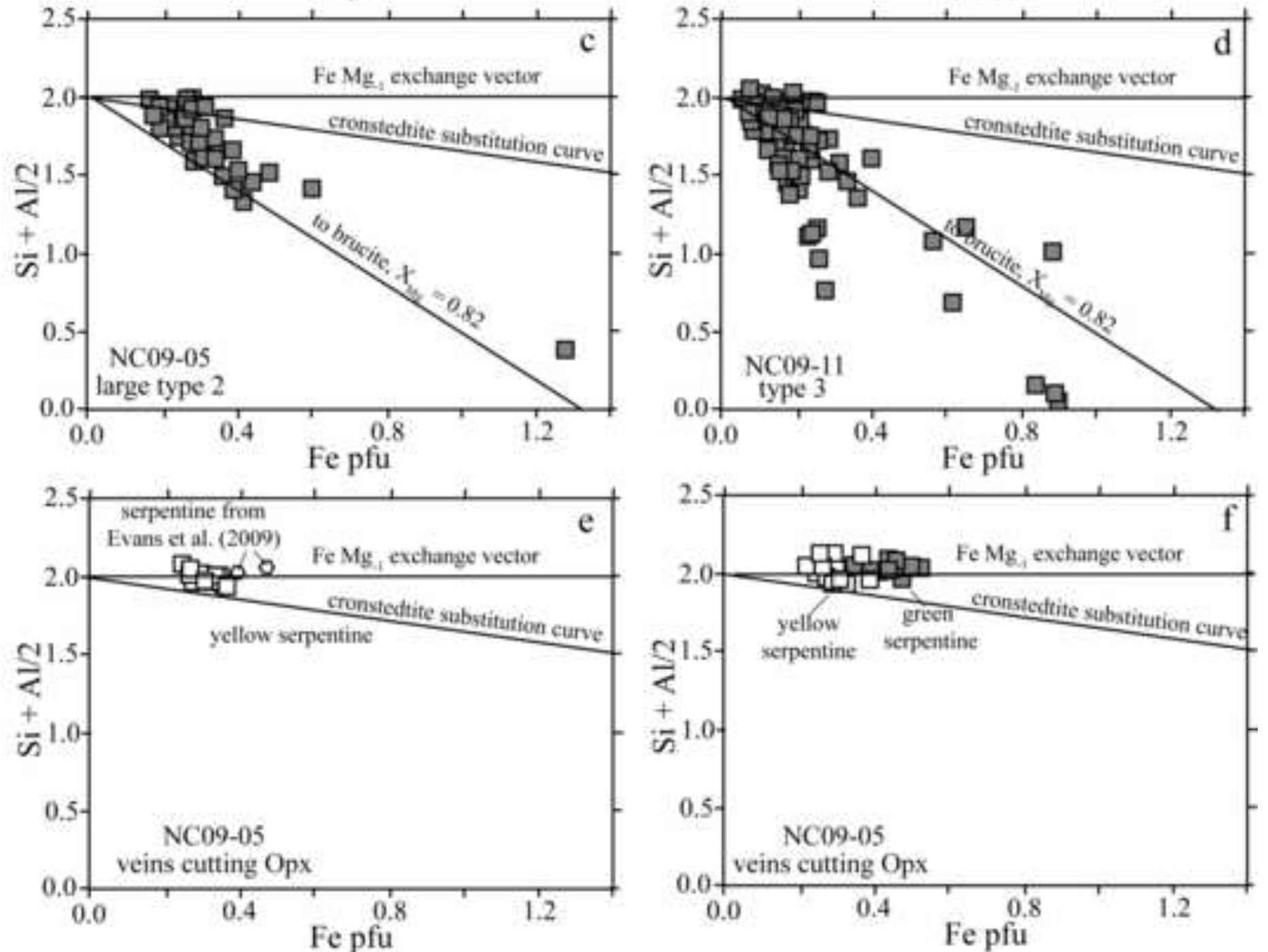

Frost et al., Fig. 13 


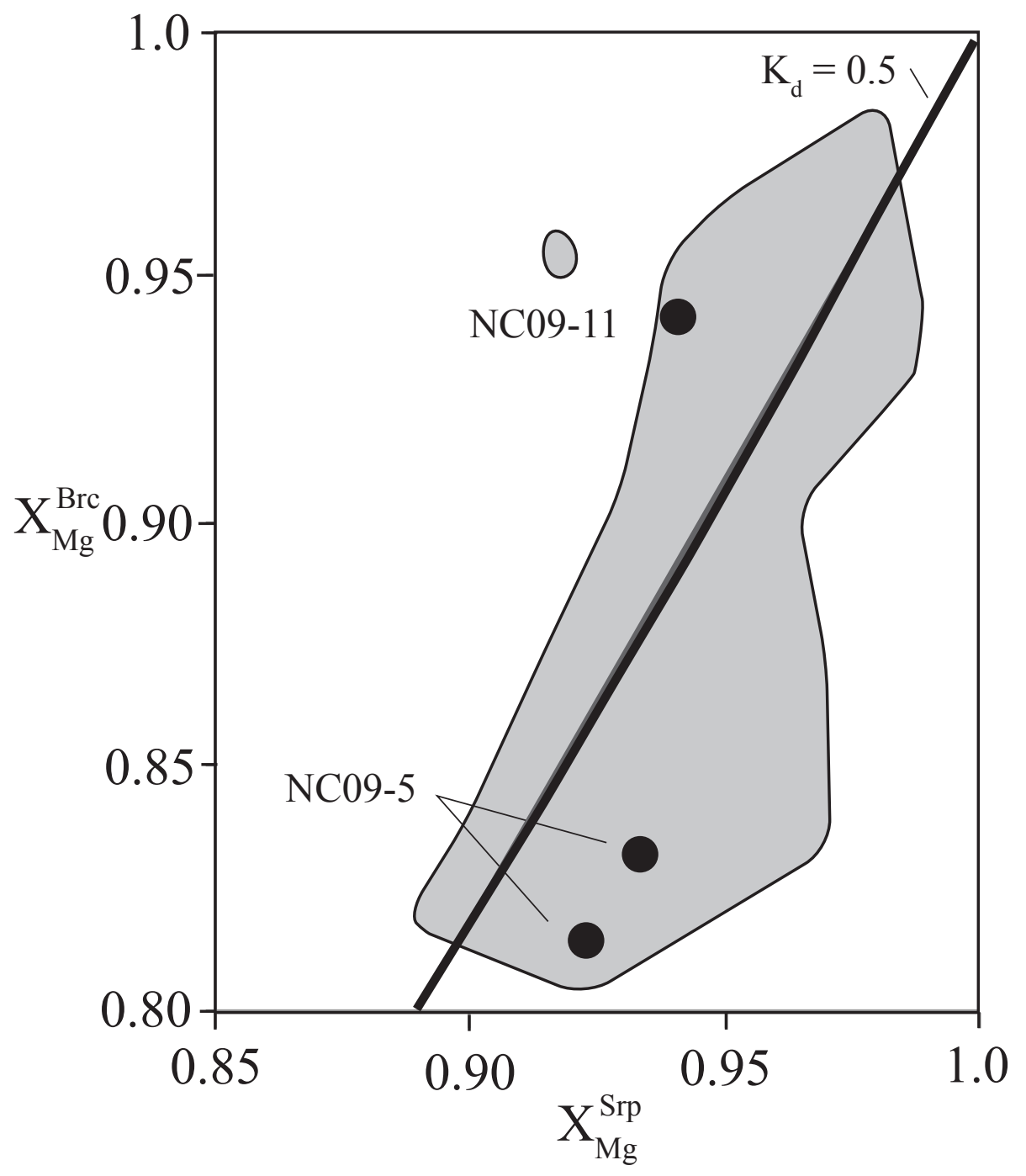

Frost et al. Fig. 14 

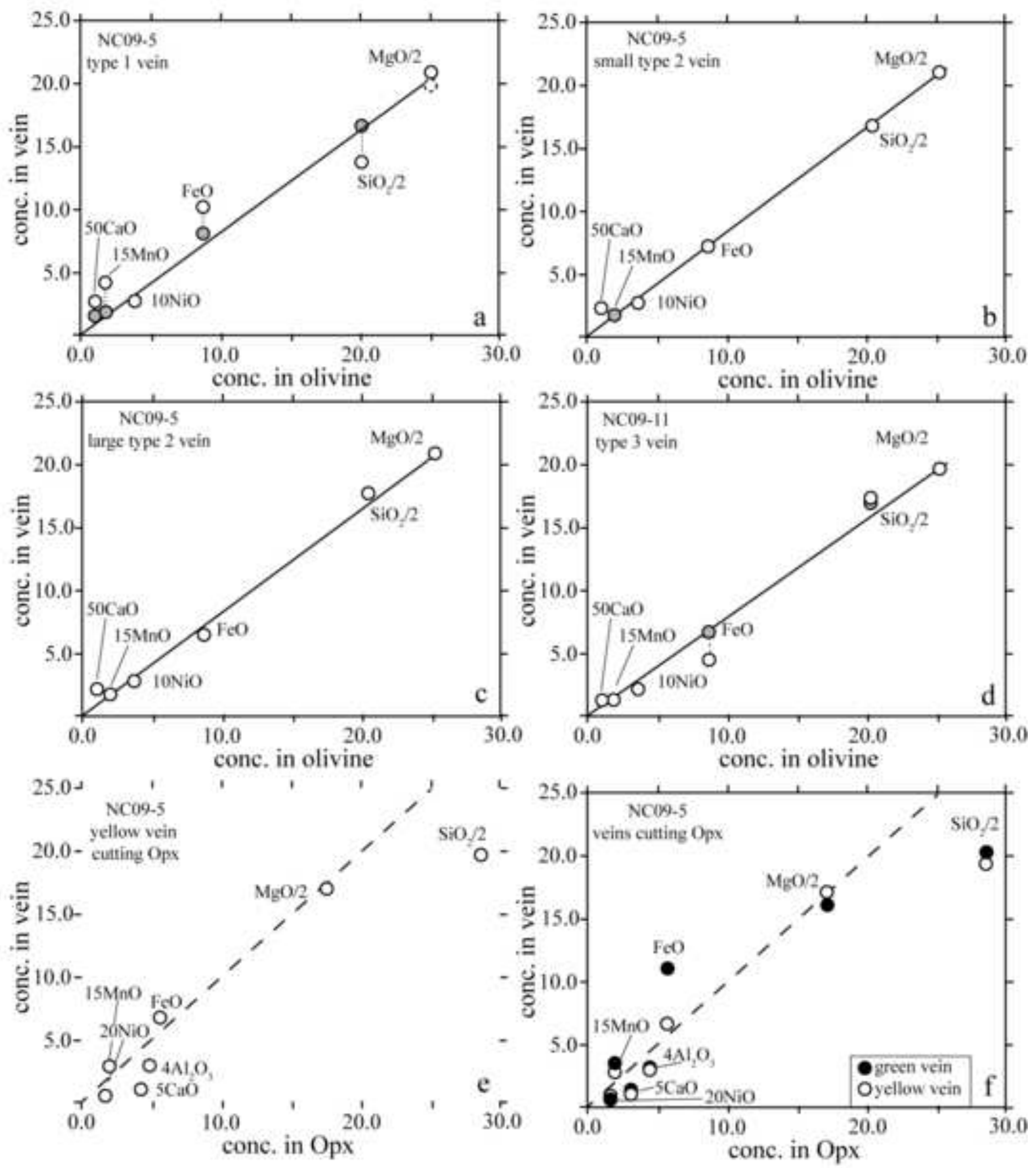

Frost et af. Fig. 15 

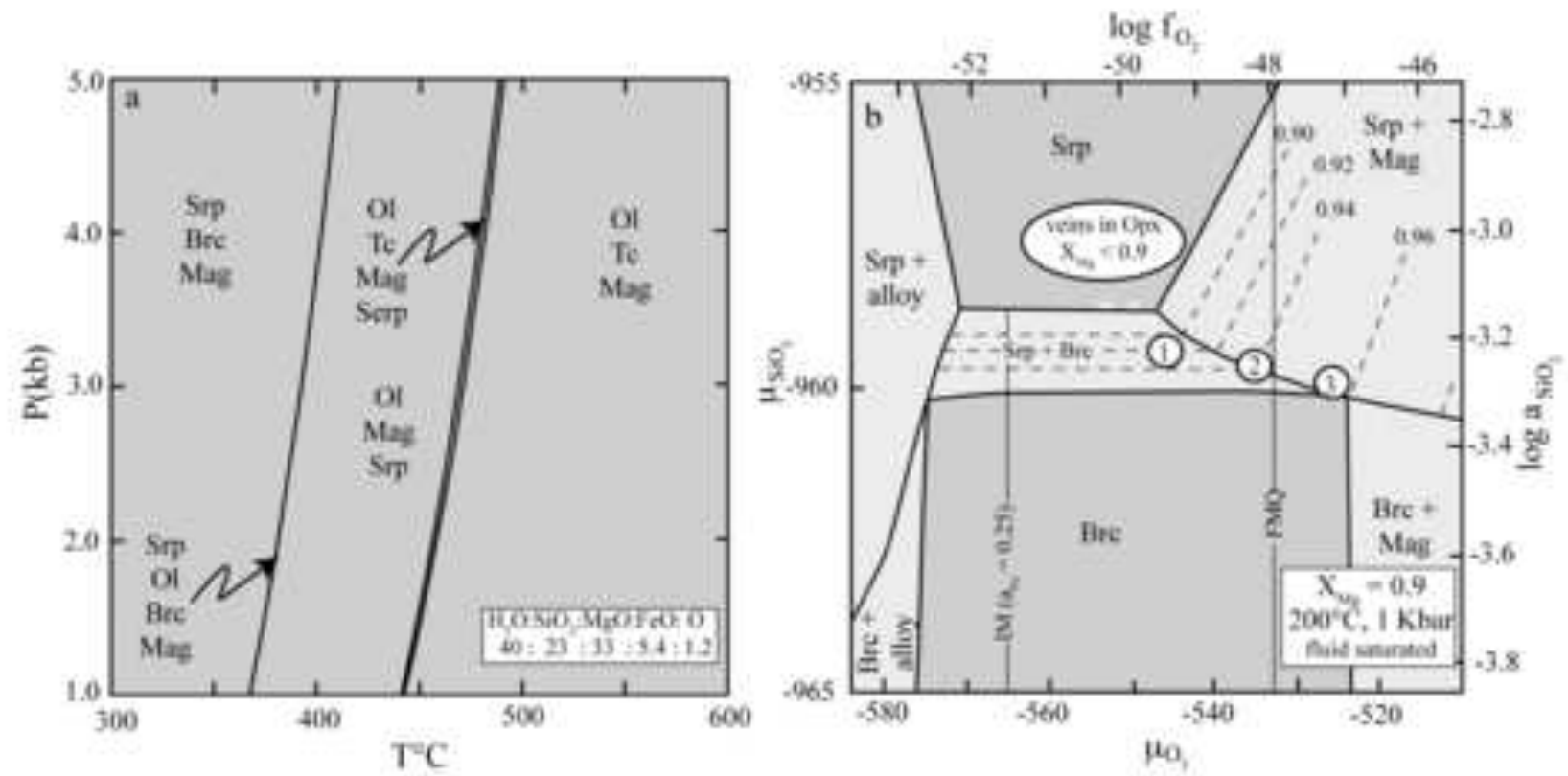

Frost et af. Fig. 16 


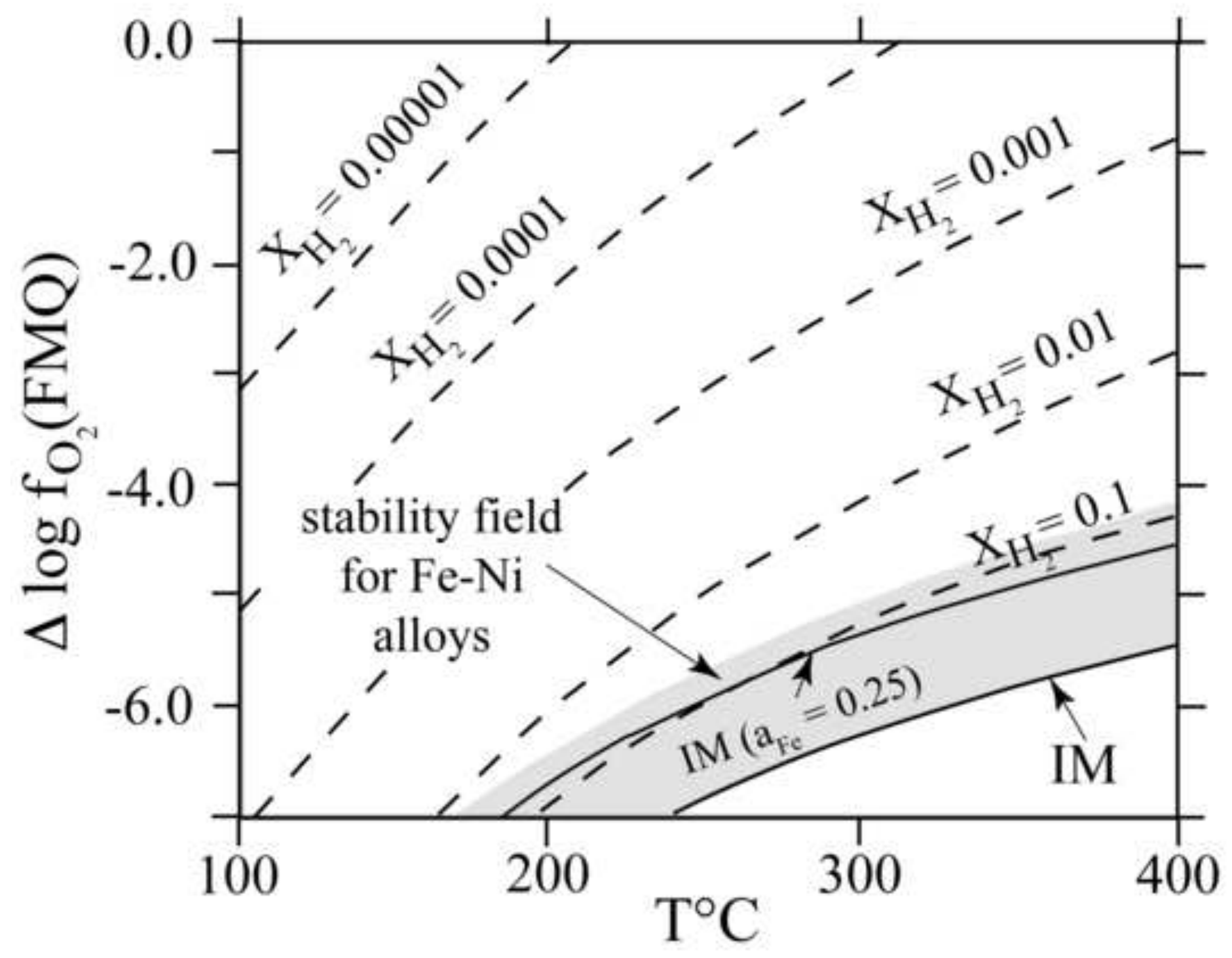

Frost et al., Fig. 17 
lightly serpentinized

highly serpentinized

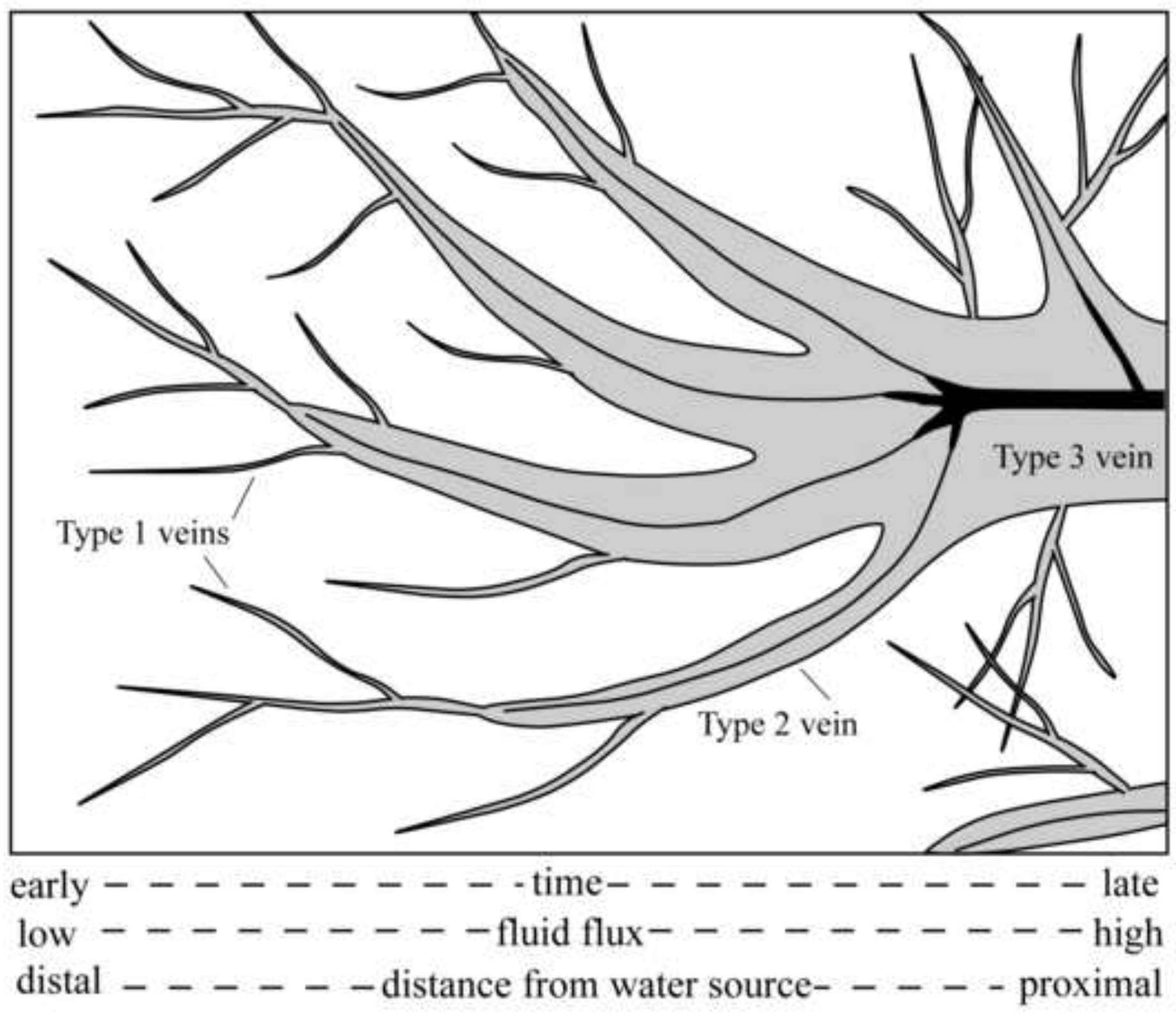

Frost et al., Fig. 18 


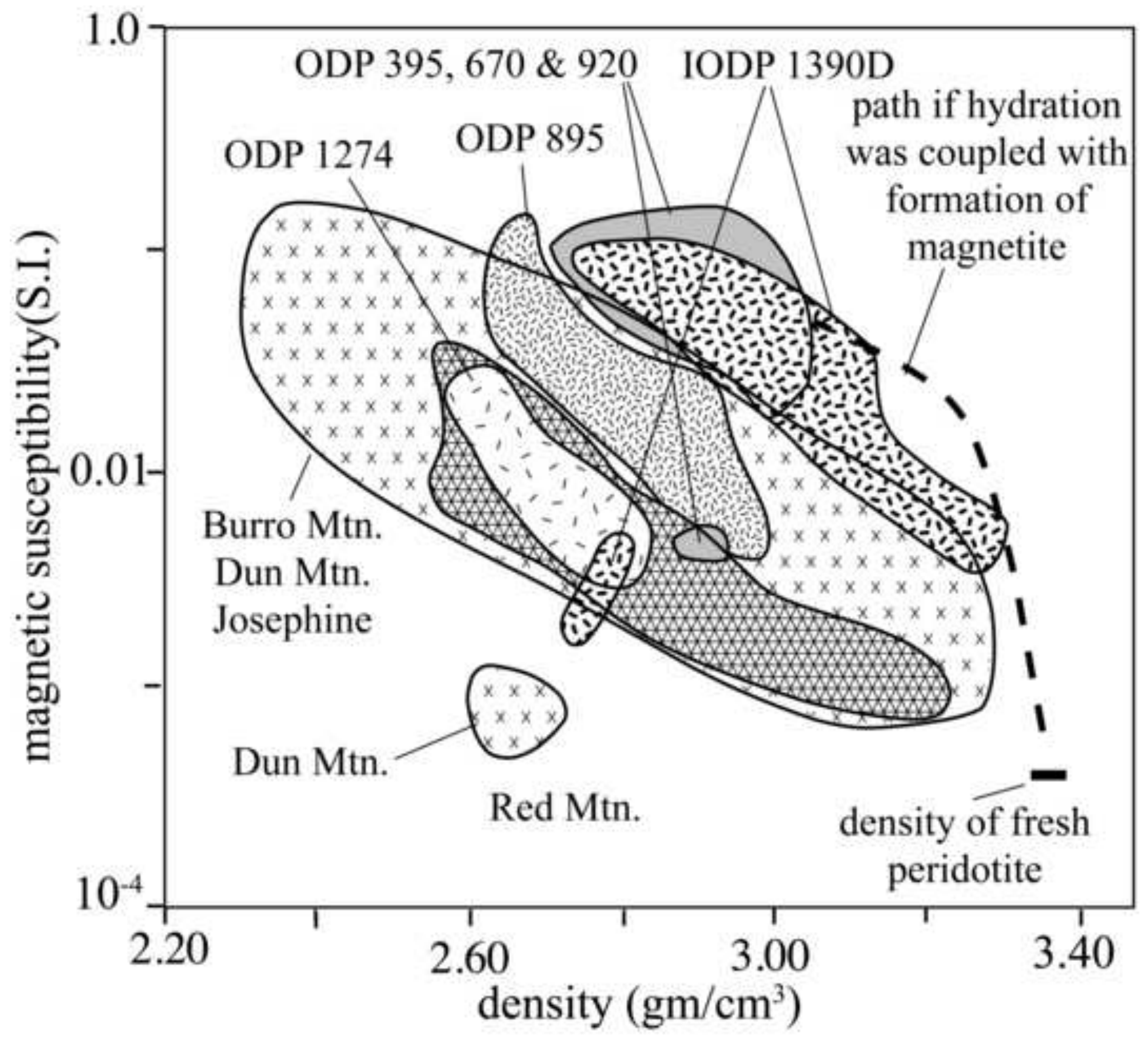

Frost et al., Fig. 19 